\title{
Study on the groundwater sustainable problem by numerical simulation in a multi-layered coastal aquifer system of Zhanjiang, China
}

\author{
Pengpeng Zhou ${ }^{1, *}$, Ming $\mathrm{LI}^{2}$ and Yaodong $\mathrm{Lu}^{3}$ \\ ${ }^{1}$ Key Laboratory of Shale Gas and Geoengineering, Institute of Geology and Geophysics, Chinese Academy of \\ Sciences, No. 19 Beitucheng West Road, Chaoyang District, Beijing 100029, China. \\ ${ }^{2}$ Chinese Research Academy of Environmental Sciences, No. 8 Anwaibeiyuan Road, Chaoyang District, \\ Beijing 100012, China. \\ 3 The First Hydrogeological Team, Guangdong Geological Bureau, Kangning Road, Chikan District, \\ Zhanjiang 524049, China. \\ *Corresponding author.e-mail: zhoupengpeng@mail.iggcas.ac.cn
}

MS received 12 October 2016; revised 11 April 2017; accepted 11 April 2017; published online 7 October 2017

Assessing sustainability of coastal groundwater is significant for groundwater management as coastal groundwater is vulnerable to over-exploitation and contamination. To address the issues of serious groundwater level drawdown and potential seawater intrusion risk of a multi-layered coastal aquifer system in Zhanjiang, China, this paper presents a numerical modelling study to research groundwater sustainability of this aquifer system. The transient modelling results show that the groundwater budget was negative $\left(-3826 \times 10^{4}\right.$ to $\left.-4502 \times 10^{4} \mathrm{~m}^{3} / \mathrm{a}\right)$ during the years $2008-2011$, revealing that this aquifer system was over-exploited. Meanwhile, the groundwater sustainability was assessed by evaluating the negative hydraulic pressure area (NHPA) of the unconfined aquifer and the groundwater level dynamic and flow velocity of the offshore boundaries of the confined aquifers. The results demonstrate that the Nansan Island is most influenced by NHPA and that the local groundwater should not be exploited. The results also suggest that, with the current groundwater exploitation scheme, the sustainable yield should be $1.784 \times 10^{8} \mathrm{~m}^{3} /$ a (i.e., decreased by $20 \%$ from the current exploitation amount). To satisfy public water demands, the $20 \%$ decrease of the exploitation amount can be offset by the groundwater sourced from the Taiping groundwater resource field. These results provide valuable guidance for groundwater management of Zhanjiang.

Keywords. Numerical modelling; coastal multi-layered aquifers; groundwater resources sustainability; groundwater level dynamics; negative hydraulic pressure area; Zhanjiang.

\section{Introduction}

With the increasing demand for water resources, coastal aquifers are vulnerable to over-exploitation and contamination (Barlow and Reichard 2010; Green and MacQuarrie 2014). Therefore, coastal groundwater sustainability has become a critical issue (Gleeson et al. 2012). In coastal groundwater management, it is necessary to identify the sustainable groundwater exploitation amount and a reasonable groundwater exploitation scheme to support the groundwater sustainability. The 
sustainable groundwater exploitation amount (or sustainable yield) could be defined as the difference between groundwater recharge quantity (including natural recharge quantity and water captured by pumping) and natural discharge quantity (Alley and Leake 2004; Maimone 2004; Kalf and Woolley 2005). Maimone (2004) indicated that groundwater balance and boundary conditions must be considered in determining sustainable yield.

Numerical simulation with the predictive capability is a feasible method for solving the sustainability problems of groundwater management (Ghassemi et al. 1997; Narayan et al. 2007; Ayvaz and Karahan 2008; Rejani et al. 2008, 2009; Singh 2010, 2014; Lu et al. 2013). The simulation results of existing or proposed groundwater management schemes can help to identify the sustainable groundwater exploitation amount and a reasonable groundwater exploitation scheme for the future (Paniconi et al. 2001; Zhou et al. 2003; Barazzuoli et al. 2008; Jhorar et al. 2009; Pongkijvorasin et al. 2010; Chandio et al. 2012; Nocchi and Salleolini 2013; El-Kadi et al. 2014; Yidana et al. 2015; Lathashri and Mahesha 2016).

For numerical modelling studies on coastal groundwater sustainable problems, designing optimal groundwater exploitation management schemes and assessing seawater intrusion are always the most important research objectives. Sefelnasr et al. (2015) obtained sustainable groundwater management options for the Nubian sandstone aquifer in Sahara through simulations using FEFLOW. Jang et al. (2016) established an optimal water supply strategy of joint groundwater and surface water use in Pingtung Plain by using MODFLOW. Alfaro et al. (2017) presented a numerical groundwater model using MODFLOW to simulate a reasonable groundwater pumping scheme for Jordan Valley. With the simulating capacity of variabledensity groundwater flow, the SEAWAT program is widely used to solve seawater intrusion issues in coastal areas. Yi et al. (2016) quantitatively simulated the seawater intrusion rate and its seasonal changes in the coastal aquifer in Tianjin, China. Considering parameter uncertainty, Zeng et al. (2016) simulated the seawater intrusion risk of a groundwater resource field in Laizhou Bay, China.

Except for the groundwater model, the coupled surface and subsurface numerical model is also applied in sustainable water assessment. To diminish the high computational cost of the basin-scale integrated surface water-groundwater modelling, Wu et al. (2015) developed a new surrogate-based optimization approach. Using the fully coupled surface and subsurface numerical model (HydroGeoSphere), Yu et al. (2016) simulated the impact of coastal topographic features on surge-induced groundwater salinization. By coupling the surface water (SWAT), groundwater (MODFLOW) and solute transport (MT3DMS) models, Eshtawi et al. (2016) simulated the groundwater dynamics of the coastal area of Gaza Strip and investigated the effectiveness of some non-conventional water resources utilization schemes for sustainable water planning. Dogrul et al. (2016) presented a linked groundwater-reservoir system simulation model for sustainable management of water resources in California's Central Valley. In addition, multi-objective simulation-optimization models are also widely used in studies on coastal groundwater sustainability (Sreekanth and Datta 2010; Kourakos and Mantoglou 2011, 2013; Heydari et al. 2016; RenauPruñonosa et al. 2016).

In recent years, climate change (such as sea level rise and precipitation change) and its potential influence on coastal groundwater has been a worldwide concern (Werner and Simmons 2009; Webb and Howard 2011; Ferguson and Gleeson 2012; Green and MacQuarrie 2014; Lemieux et al. 2015). Costal groundwater modelling is frequently used to analyze the influences of climate change. Knowling et al. (2015) presented a highly parameterized groundwater model and quantitatively evaluated the relative contributions of climate and human stress to groundwater depletion in Uley South Basin, Australia. De Filippis et al. (2016) assessed the saltwater intrusion status of a karstic coastal aquifer in Taranto under natural and human forcing. Considering the sea level rise, Wassef and Schüttrumpf (2016) built a threedimensional numerical model for groundwater in a delta of Egypt and discussed the impact of sea level rise on the local groundwater. Mehdizadeh et al. (2017) investigated the gradual and instantaneous sea level rise effects on seawater intrusion dynamics by using SEAWAT.

Zhanjiang city is located in the coastal area of Guangdong, China. The groundwater in the middle and deep confined aquifers has been the major water resource of this city since the 1960s. Due to intense groundwater pumping for public use, the groundwater level of the confined aquifers has been sustained to decline and has dropped to approximately $20 \mathrm{~m}$ below the mean sea level after the 
1990s (Su 2005; Zhou et al. 2007; First Hydrogeological Team 2009a). Influenced by the remarkable decline of groundwater level, the two confined aquifers are partly recharged by lateral flux from the ocean direction. Despite the above disadvantageous hydraulic conditions (i.e., low groundwater level and landward recharge flux), groundwater in the middle and deep confined aquifers, which are separated by a clay layer from the upper unconfined aquifer and extend under the seabed for a long distance, is still fresh water with a TDS of $73.4-252.94$ and $101.48-323.93 \mathrm{mg} / \mathrm{L}$ in the middle and deep confined aquifers respectively (First Hydrogeological Team 2012). However, for the upper unconfined aquifer, some recent studies about the groundwater chemistry of islands located in the southern area of Zhanjiang city show that a part of the unconfined groundwater has suffered from seawater intrusion ( $\mathrm{Su} 2005$; Luo and Su 2007; Zhang et al. 2012; Teng et al. 2014). It is worrying that the confined groundwater will be risky in suffering from saltwater intrusion due to continuous groundwater demand, low confined groundwater level and landward recharge flow.

Therefore, groundwater sustainability and seawater intrusion risk must be assessed for effective groundwater management of Zhanjiang city. The multi-layered coastal aquifer system of Zhanjiang has unique hydraulic, hydrochemical and hydrogeological conditions. Therefore, it is valuable to conduct groundwater modelling work on this coastal aquifer system to add scientific contributions to the field of hydrogeology.

To quantitatively assess groundwater sustainability and seawater intrusion risk, this paper performed a three-dimensional numerical groundwater flow model of the coastal multi-layered aquifer system of Zhanjiang. Based on this model, through scenarios simulating that consider different mean sea level rise (MSLR) and groundwater exploitation schemes, we assessed the groundwater sustainability and seawater intrusion risk by evaluating the negative hydraulic pressure area (NHPA) of the unconfined aquifer, and groundwater level dynamic and flow velocity of the offshore recharge boundaries of the confined aquifers. It should be noted that the NHPA represents the area where the unconfined groundwater level is below the mean sea level. The NHPA can be an indicator to reveal the seawater intrusion risk of the shallow unconfined aquifer. For the confined aquifers, the groundwater level dynamics and recharge flow velocities of the offshore recharge boundaries were used to indicate seawater intrusion risk.

\section{Study area and data resources}

\subsection{Study area}

Zhanjiang city is located in southwestern Guangdong, China (figure 1). The topography is high in northwest and low in southeast. The average annual precipitation is approximately $1346.6 \mathrm{~mm}$ (1957-2007) and average annual evaporation is approximately $1774.1 \mathrm{~mm}$ (First Hydrogeological Team 2009a).

According to geological investigation (Zhou et al. 2003; First Hydrogeological Team 2009a), Zhanjiang city mainly consists of continental and marine sediments of upper Tertiary-Quaternary age overlying a basement of mudstone and silty sandstone of Cretaceous age. Those unconsolidated sediments constitute a multi-layered aquifer system. This multi-layered aquifer system can be divided into three aquifers (the unconfined aquifer, middle confined aquifer and deep confined aquifer) separated by clay layers (aquitards) (figure 2).

The unconfined aquifer has a thickness of approximately $30 \mathrm{~m}$ and is composed of fine to coarse sand. This unconfined aquifer overlies a layer of 14-18 m thick clay that extends laterally under the seabed for a long distance. The hydraulic conductivity $(K)$ is $5-25 \mathrm{~m} / \mathrm{d}$. The groundwater flow field remains as an approximately natural flow regime with water table of $0-60 \mathrm{~m}$ above the mean sea level (figure 3a). This aquifer is mainly recharged by rainfall infiltration and is discharged through evaporation and run-off to the ocean.

The middle confined aquifer has a thickness of $50-140 \mathrm{~m}$ and is composed of medium to coarse sand. This aquifer is characterized by great hydraulic conductivity of $20-60 \mathrm{~m} / \mathrm{d}$. After years of exploitation since the 1960s, the middle confined groundwater level has dropped from -24 to $\times 16 \mathrm{~m}$ (figure $3 \mathrm{~b}$ ). The two centers of the groundwater depression cones are located in the Pingle and Linhai respectively (figure $3 \mathrm{~b}$ ). This confined aquifer is mainly recharged via lateral run-off and leakage, and is discharged via pumping.

The deep confined aquifer, separated by a clay layer (aquitard) from the middle confined aquifer, is composed of medium to coarse sand. This confined aquifer is also quite permeable (hydraulic conductivity of $20-50 \mathrm{~m} / \mathrm{d}$ ) and is extensively used 


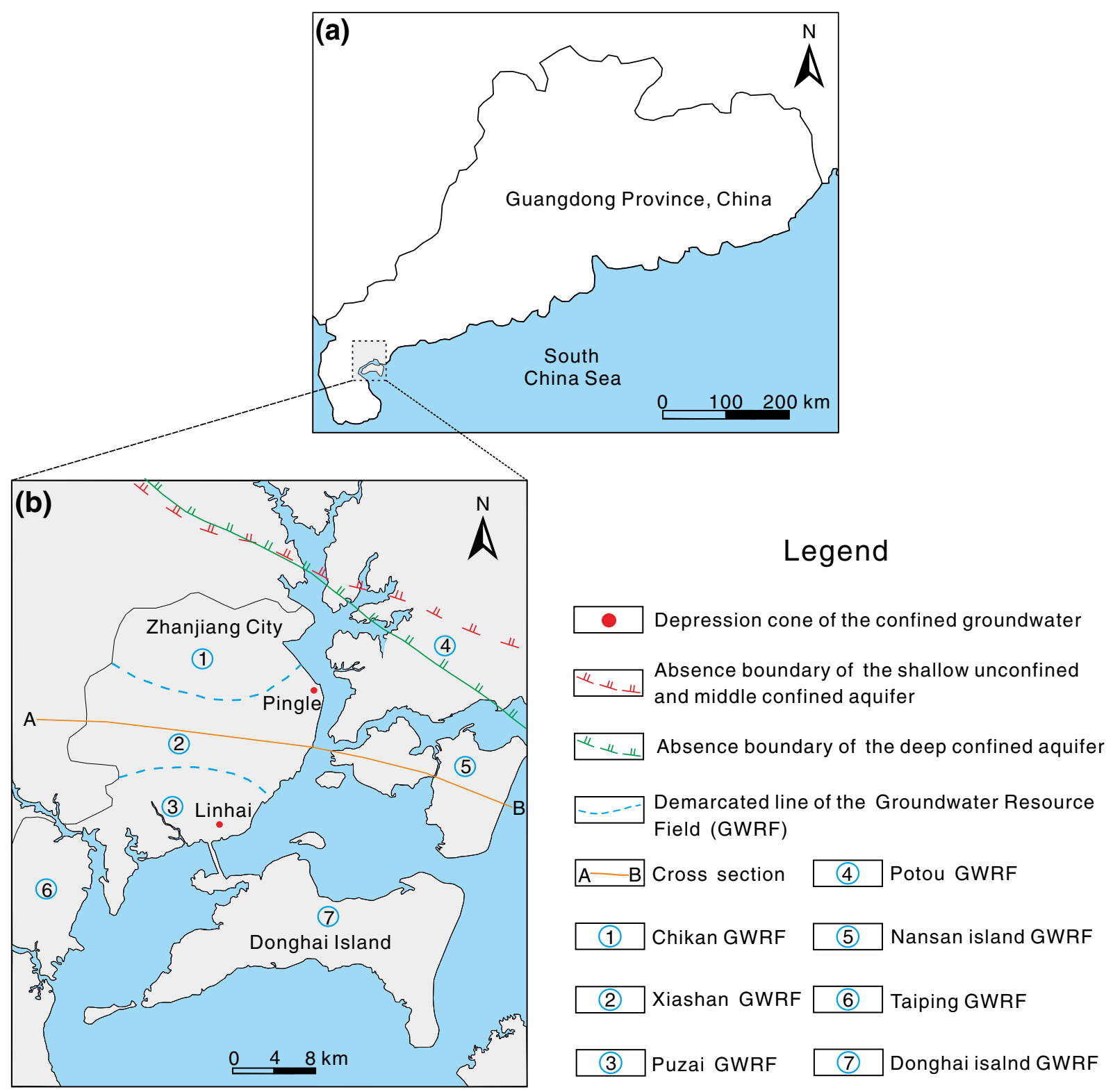

Figure 1. Location map of Zhanjiang city (Line A-B illustrates the location of hydrogeological cross-section displayed in figure 2). (a) Map of Guangdong province and (b) Map of Zhanjiang city.

for municipal wells. The groundwater level has dropped from -22 to $\sim-4 \mathrm{~m}$ (figure $3 \mathrm{c}$ ). This deep confined aquifer is mainly recharged via lateral runoff and leakage and is discharged via pumping.

\subsection{Data source}

In this study, the monthly precipitation data during the period January 2008-December 2011 were acquired from the Zhanjiang Hydrology Bureau. The monthly groundwater level data in 45 observation wells during the period January 2008-December 2011, the geodesic coordinates of the wells and the descriptions of the basic hydrogeological conditions were obtained from the First Hydrogeological Team, Guangdong Geological Bureau.

\section{Numerical modelling of the study area}

\subsection{Software}

In this study, the numerical groundwater model MODFLOW was used to develop a regional model to simulate groundwater level dynamics and assess 


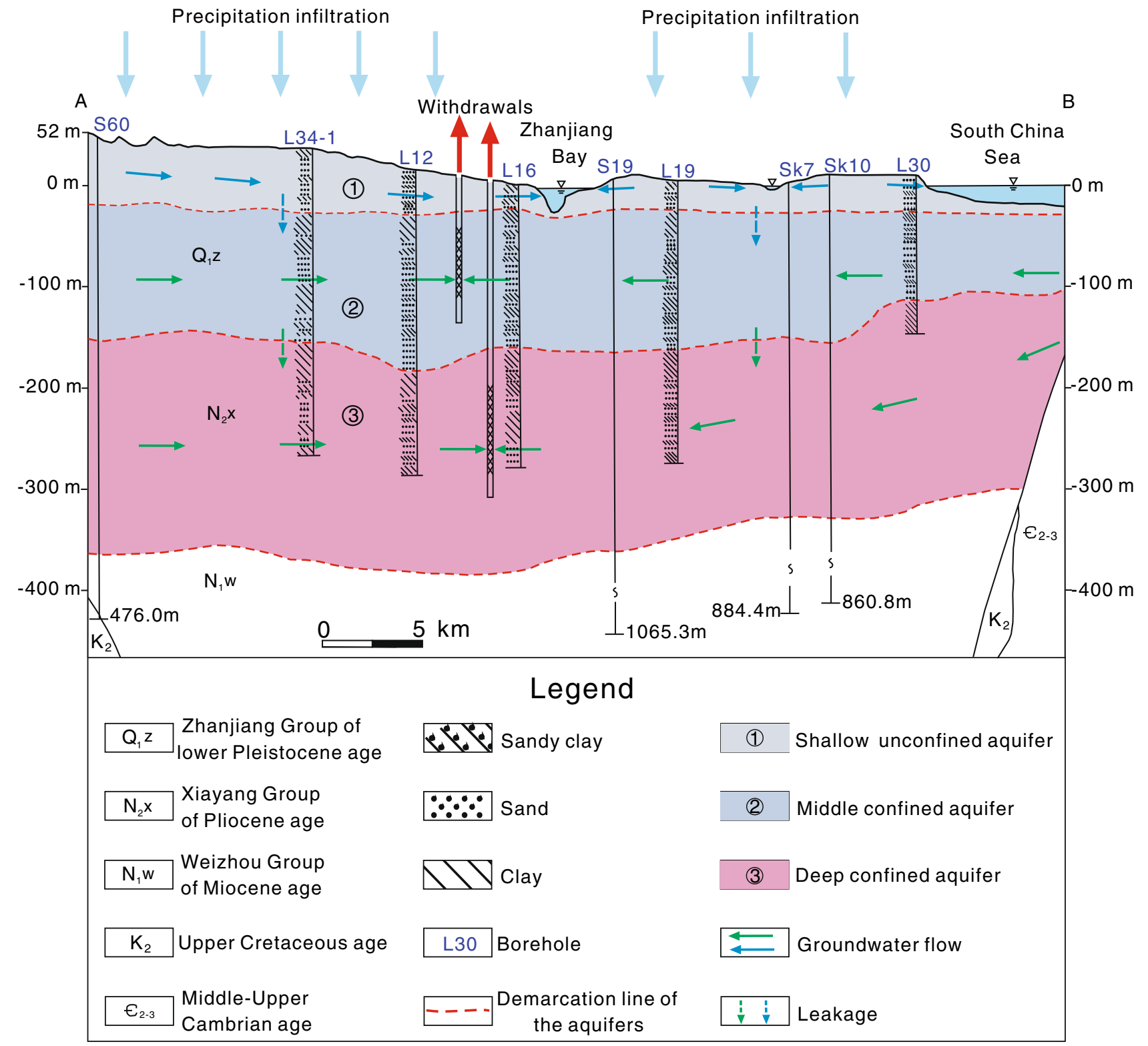

Figure 2. Hydrogeological cross-section (A-B line in figure 1) of the study area.

groundwater sustainability for the coastal multi-layered aquifer system of Zhanjiang.

\subsection{Model discretization}

The model domain is $50 \mathrm{~km}$ long, $60 \mathrm{~km}$ wide, and up to $500 \mathrm{~m}$ deep. In the plane view, the model's discretized cells are $100 \times 120 \mathrm{~m}$. In the vertical view, the model was divided into five layers. From top to bottom, those five modeled layers represent the shallow unconfined aquifer, the upper aquitard, the middle confined aquifer, the lower aquitard, and the deep confined aquifer, respectively. The model domain was discretized to 792,688 effective quadrilateral cells (500 columns, 500 rows, and 5 layers) (figure 4).

The thickness of each model layer was determined by the interpolation result of the borehole data. The transient simulation period was four years from January 2008 to December 2011, and a total of 48 stress periods was used in the transient simulation.

\subsection{Boundary conditions}

Details of the boundary conditions are shown in figure 5. A specified flux boundary was assigned to simulate the rainfall recharge and evaporation at the phreatic surface. A no-flow boundary was 




Figure 3. Groundwater level contour maps for the multi-layered aquifers. (a) The shallow unconfined aquifer; (b) the middle confined aquifer; and (c) the deep confined aquifer.

adopted for the model bottom due to the contact with low-permeability argillaceous sandstone.

First, for the unconfined aquifer, because the Zhanjiang Bay and sea by going rivers contact with the porous unconfined aquifer, specified-head boundary conditions of zero metres representing the mean sea level and river level were assigned at the coast/river edges. Contacting the lowpermeabile uplifted bedrock, the northeast boundary of the porous unconfined aquifer was set with a no-flow boundary (figure 5a). The other boundaries (i.e., the northwest and west boundaries) perpendicular to unconfined groundwater level contours were assigned with no-flow boundary conditions (figure 5a).

Second, for the middle and deep confined aquifers, details of the boundary conditions are shown in figures 5(b and c). Pinching out and contacting with the low-permeabile uplifted bedrock, no-flow boundaries were set at the northeast boundaries. The other boundaries were assigned with specifiedflux boundary conditions that were determined by the Darcy law. Based on hydrogeological investigation, it is doubtless that the two confined aquifers and their roofs extend under the sea bed for a long distance and that the two confined aquifers are also recharged by the run-off from southern and eastern areas. As a result, in our model, the southern and eastern boundaries of the two confined aquifers were extended beyond the coastline for a certain distance and set with specified-flux boundary conditions.

\subsection{Initial flow conditions}

The initial flow conditions were determined by observed groundwater level data during December 2007 (figure 3). In our modelling study, a steady state simulation of December 2007 was first conducted to generate the initial groundwater flow field calibrated by the observed data. Then, the computed result of the steady flow field served as the initial flow condition for the transient simulations.

\subsection{Recharge and discharge conditions}

For this modelling domain, the groundwater is mainly recharged by the meteoric infiltration and lateral run-off, and discharged by groundwater withdrawal, run-off and evaporation. 


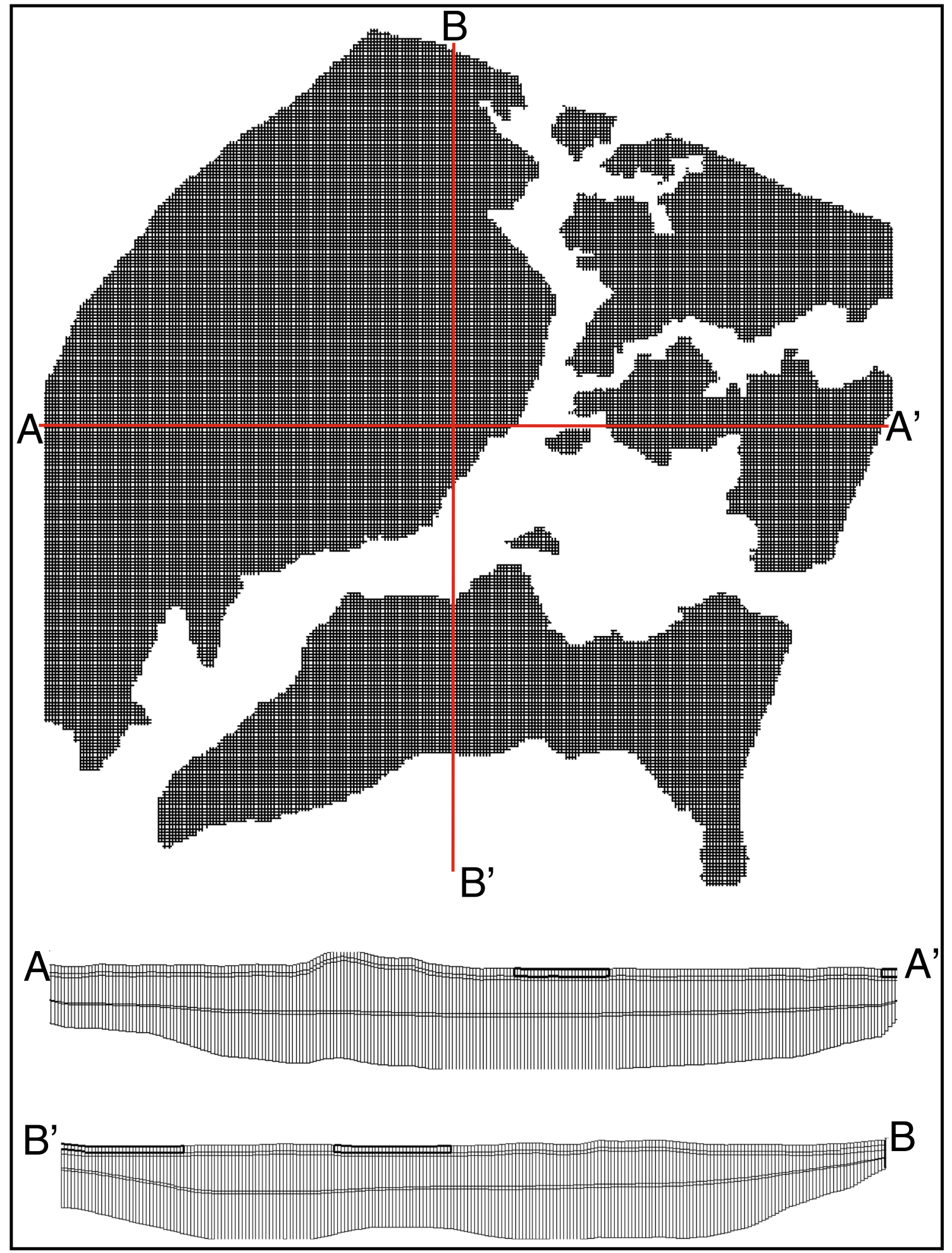

Figure 4. MODFLOW grid map of the model domain.

\subsubsection{Recharge conditions}

For the studied aquifer system, precipitation infiltration $(P e)$ is the main recharge resource. The $P e$ was initially estimated according to the general calculation formula (i.e., $P e=\alpha \cdot F \cdot P$, in this formula, $\alpha$ is the coefficient of precipitation, $F$ is the recharged area by precipitation infiltration, and $P$ is the precipitation). According to the hydrogeological investigation (First Hydrogeological Team 2009a), the areal recharge of the unconfined aquifer can be divided into three zones 


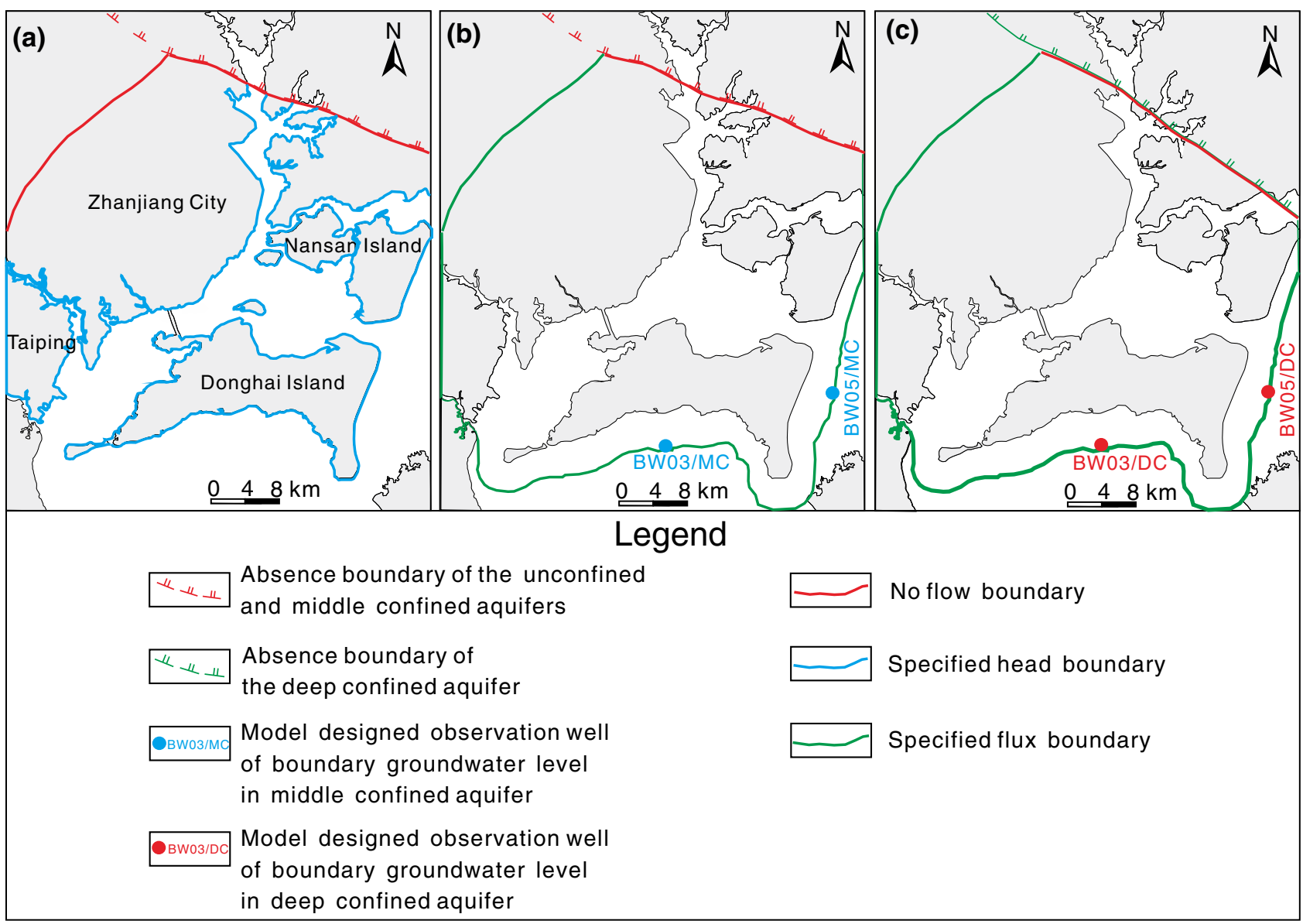

Figure 5. The boundary conditions of the model layers. (a) The shallow unconfined aquifer; (b) the middle confined aquifer; and (c) the deep confined aquifer.

with different $\alpha$ values (figure 6). For simulation of steady-state conditions, the $P e$ values were calculated based on the annual precipitation value of 2007 (table 1). For the transient simulation, the $P e$ values were calculated based on the monthly precipitation values from January 2008 to December 2011 (figure 7).

Lateral run-off is also a main recharge source, especially for the middle and deep confined aquifers. According to groundwater flow investigation (figure 3), the modeled confined aquifers are recharged by lateral run-off from the northwest, west, south and east boundaries. The lateral recharge fluxes of the middle and deep confined aquifers were calculated by the Darcy law (table 2). For the middle confined aquifer, the recharge flux was $2345.07 \times 10^{4} \mathrm{~m}^{3} /$ a from the northwest boundary, $783.43 \times 10^{4} \mathrm{~m}^{3} /$ a from the west boundary, and $727.80 \times 10^{4} \mathrm{~m}^{3} / \mathrm{a}$ from the south and east boundaries. For the deep confined aquifer, the recharge flux was $3251.82 \times 10^{4} \mathrm{~m}^{3} / \mathrm{a}$ from the northwest and west boundaries and $1023.93 \times 10^{4} \mathrm{~m}^{3} / \mathrm{a}$ from the south and east boundaries.

\subsubsection{Discharge conditions}

Lateral discharge mainly occurs on the coastline through groundwater run-off into the sea and rivers. According to Darcy law, the lateral discharge flux was estimated to be $37098.6 \times 10^{4} \mathrm{~m}^{3}$ (table 2). According to the water resources bulletin of Zhanjiang city, groundwater discharge from withdrawal used for drinking and farming was $2.18 \times 10^{8} \mathrm{~m}^{3}$ during 2007 .

\subsection{Parameters and calibration}

The main objective of calibration is to obtain reasonable results matching the field monitoring data by adjusting the parameters that can characterize the aquifer system. In this study, using the groundwater level data measured in December 2007, a preliminary calibration for the steady groundwater flow model was initially conducted to estimate the distribution of hydraulic conductivity $(K)$. The anisotropy ratio $K z / K x$ (vertical $v s$. horizontal hydraulic conductivity) was 0.1 . For 


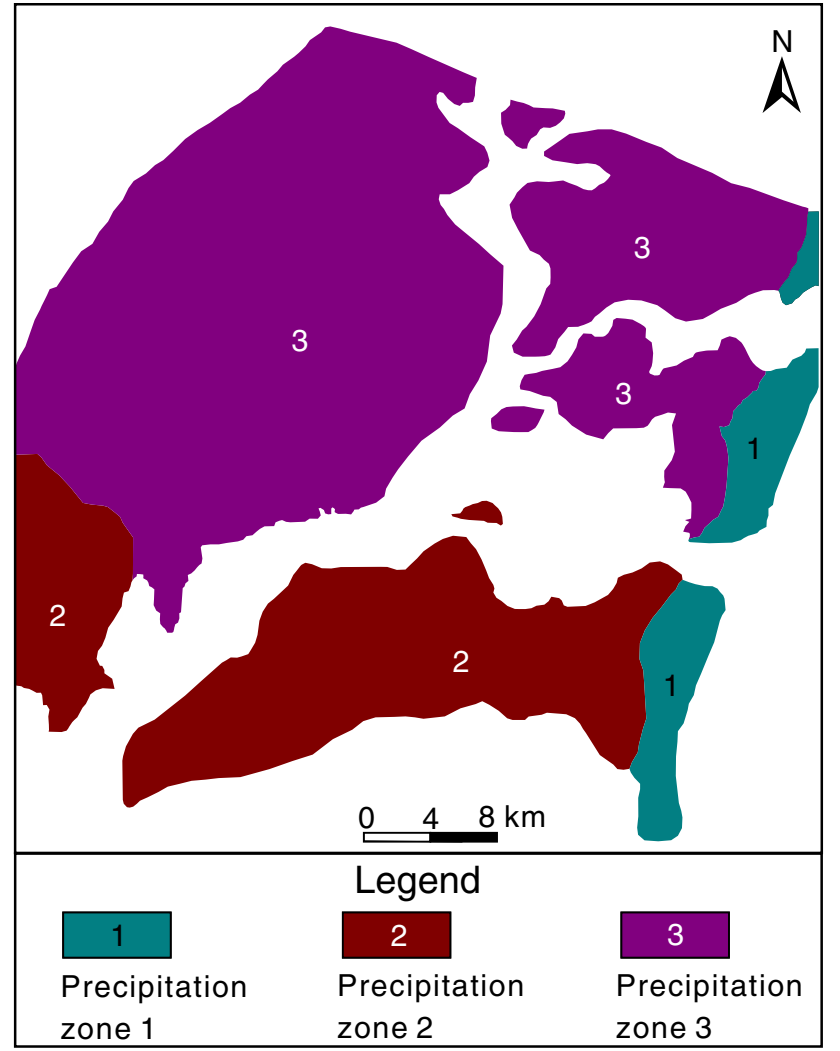

Figure 6. Areal recharge zones chart of the modelled shallow unconfined aquifer.

Table 1. The precipitation infiltration $(\mathrm{Pe})$ of the steady-state simulation.

\begin{tabular}{lcccc}
\hline & & $F$ & $P$ & $P e$ \\
Zones & $\alpha$ & $\left(\mathrm{km}^{2}\right)$ & $(\mathrm{mm} / \mathrm{a})$ & $\left(\times 10^{4} \mathrm{~m}^{3} / \mathrm{a}\right)$ \\
\hline 1 & 0.46 & 154.21 & & 9142.19 \\
2 & 0.33 & 369.79 & 1288.7 & 15726.09 \\
3 & 0.26 & 967.26 & & 32409.54 \\
Total & & & & 57277.82 \\
\hline
\end{tabular}

the unconfined aquifer, the calibrated $K$ values are generally higher towards the west and south area $(K=14-20 \mathrm{~m} / \mathrm{d})$ and lower in the northwest area and east coastal area $(\mathrm{K}=6-10 \mathrm{~m} / \mathrm{d})$. For the middle and deep confined aquifers, the calibrated $K$ values are greater in the southwest area with better water-abundance, and lower in the north area with weaker water-abundance. The calibrated zonations of $K$ values are illustrated in figure 8 .

By comparing the simulated groundwater level contours with the measured data in December 2007 , it shows that the simulated results of groundwater level are reasonable (figure $9 \mathrm{a}-\mathrm{c}$ ). Figure $9(\mathrm{~d}-\mathrm{f})$ shows a good fit between measured and calculated groundwater level data from 45

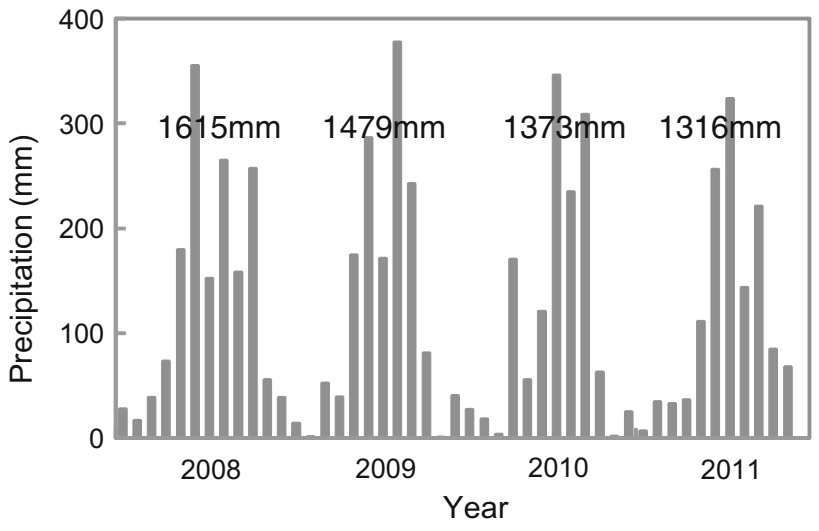

Figure 7. Monthly precipitations during 2008-2011 period of Zhanjiang.

observation wells ( 8 observation wells in the unconfined aquifer, 22 observation wells in the middle confined aquifer, and 15 observation wells in the deep confined aquifer). The root mean square error (RMSE) values of the calculated groundwater level for the unconfined aquifer, middle confined aquifer and deep confined aquifer is $1.40,2.62$ and $0.73 \mathrm{~m}$, respectively.

The model was subsequently calibrated for transient conditions. This calibration had a start time of January 2008 and an end time of December 2011, lasting for 48 months in total. The simulated groundwater level under steady conditions was assigned as the initial conditions for this transient simulation. The tidal oscillation was not taken into consideration in this transient simulation. The monthly precipitation infiltration values were calculated based on monthly precipitation values (figure 7). The yearly amounts of groundwater withdrawal were assigned by analyzing the statistical data of the water resources from bulletins of Zhanjiang city during the period 2008-2011. In each year, 12 monthly groundwater withdrawal values varied on the basis of use during different seasons. For example, public-supply wells withdrawal, which constituted approximately $42 \%$ of the total groundwater withdrawal, varied between summer to autumn (April-October) and spring (November-March); agricultural irrigation wells, which constituted approximately $44 \%$ of the total groundwater withdrawal, mainly exploited groundwater in the spring-summer period; and industrial wells withdrawal, which constituted approximately $14 \%$ of the total groundwater withdrawal, was almost stable throughout the year.

The calibration results for the transient conditions were obtained by comparing simulated 
Table 2. Lateral boundaries' recharge/discharge fluxes estimated by Darcy Law.

\begin{tabular}{|c|c|c|c|c|c|c|c|}
\hline Aquifer & Boundary & $\begin{array}{c}K \\
(\mathrm{~m} / \mathrm{d})\end{array}$ & $\begin{array}{l}\text { Hydraulic } \\
\text { gradient }\end{array}$ & $\begin{array}{l}\text { Boundary's } \\
\text { width }(\mathrm{m})\end{array}$ & $\begin{array}{l}\text { Aquifer's } \\
\text { thickness (m) }\end{array}$ & $\begin{array}{l}\text { Time } \\
\text { (d) }\end{array}$ & $\begin{array}{c}\text { Boundary flux } \\
\left(\times 10^{4} \mathrm{~m}^{3} / \mathrm{a}\right)\end{array}$ \\
\hline $\begin{array}{l}\text { Unconfined } \\
\text { aquifer }\end{array}$ & Coastline & 20 & 0.0035 & 363000 & 40 & 365 & -37098.60 \\
\hline \multirow[t]{3}{*}{$\begin{array}{l}\text { Middle confined } \\
\text { aquifer }\end{array}$} & $\begin{array}{l}\text { Northwest } \\
\text { boundary }\end{array}$ & 42 & 0.0016 & 7030 & 136 & 365 & 2345.07 \\
\hline & West boundary & 42 & 0.000336 & 13580 & 112 & 365 & 783.43 \\
\hline & $\begin{array}{l}\text { South and east } \\
\text { boundaries }\end{array}$ & 42 & 0.0001 & 57200 & 83 & 365 & 727.80 \\
\hline \multirow[t]{2}{*}{$\begin{array}{l}\text { Deep confined } \\
\text { aquifer }\end{array}$} & $\begin{array}{l}\text { Northwest and } \\
\text { west boundaries }\end{array}$ & 36 & 0.000625 & 52100 & 76 & 365 & 3251.82 \\
\hline & $\begin{array}{l}\text { South and east } \\
\text { boundaries }\end{array}$ & 36 & 0.000294 & 42750 & 62 & 365 & 1023.93 \\
\hline
\end{tabular}

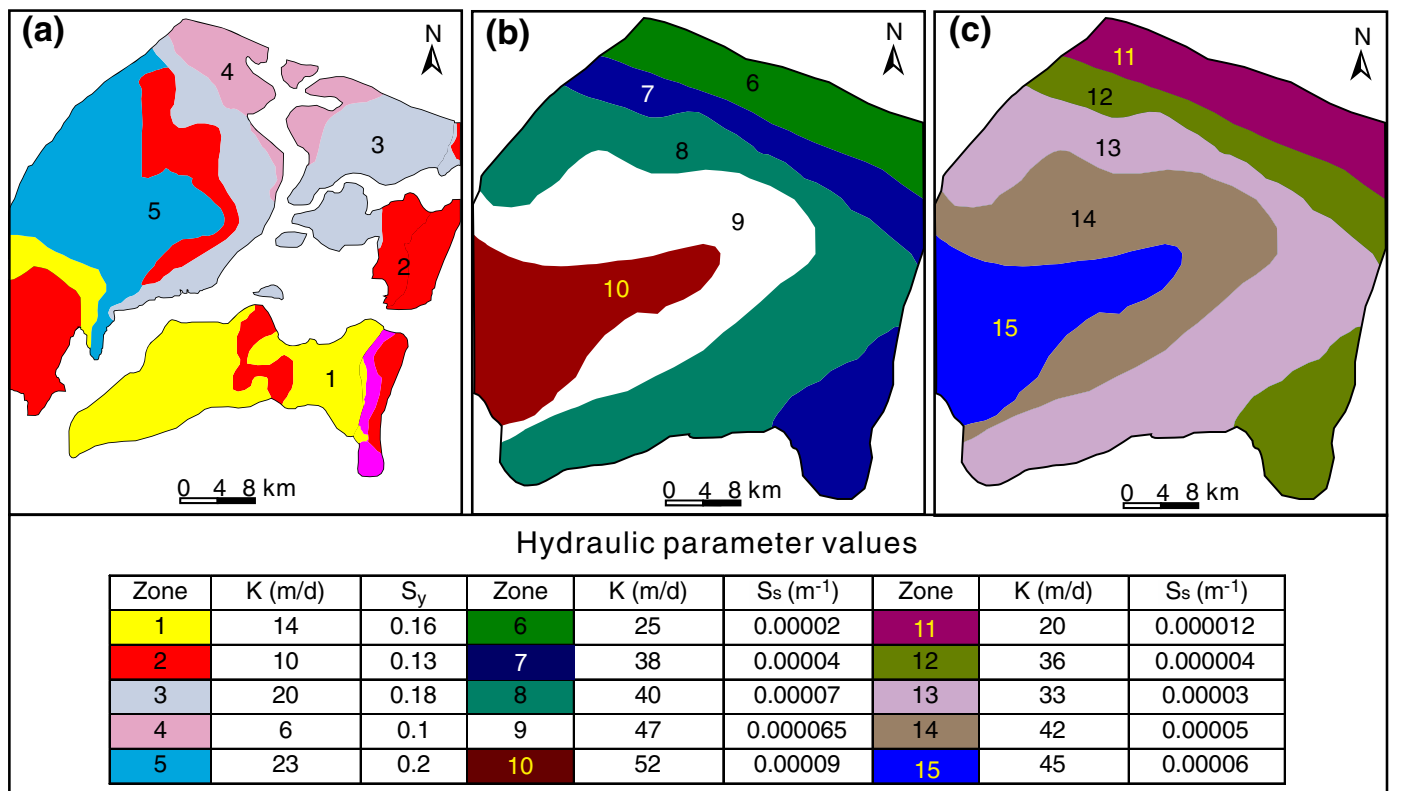

Figure 8. Zonation maps of the calibrated hydraulic parameters of the modeled aquifers. (a) The shallow unconfined aquifer, (b) the middle confined aquifer, and (c) the deep confined aquifer.

groundwater level with monitored data of 45 observation wells during January 2008 to December 2011 (figure 10). Figure 10(a-c) shows the time series graphs of simulated vs. observed groundwater levels for 12 observation wells of the unconfined aquifer, middle confined aquifer and deep confined aquifer. The location of these observation wells are displayed in figure 3 and those graphs show general similar groundwater level dynamics between simulated and observed groundwater levels data. Figure $10(d-f)$ shows a comparison between the simulated and observed groundwater levels data for all 45 observation wells during the overall calibration period of 48 months. Good agreement between calculated and observed groundwater levels was obtained. The root mean square error (RMSE) of calculated groundwater level for the unconfined aquifer, middle confined aquifer and deep confined aquifer is $1.64,2.21$ and $1.16 \mathrm{~m}$, respectively. The calibrated specific yield and specific storage are shown in figure 8 .

\subsection{Groundwater budget}

Based on the simulation under transient conditions, the groundwater budget of the Zhanjiang aquifer system over four years (January 2008December 2011) was calculated. Results of the 

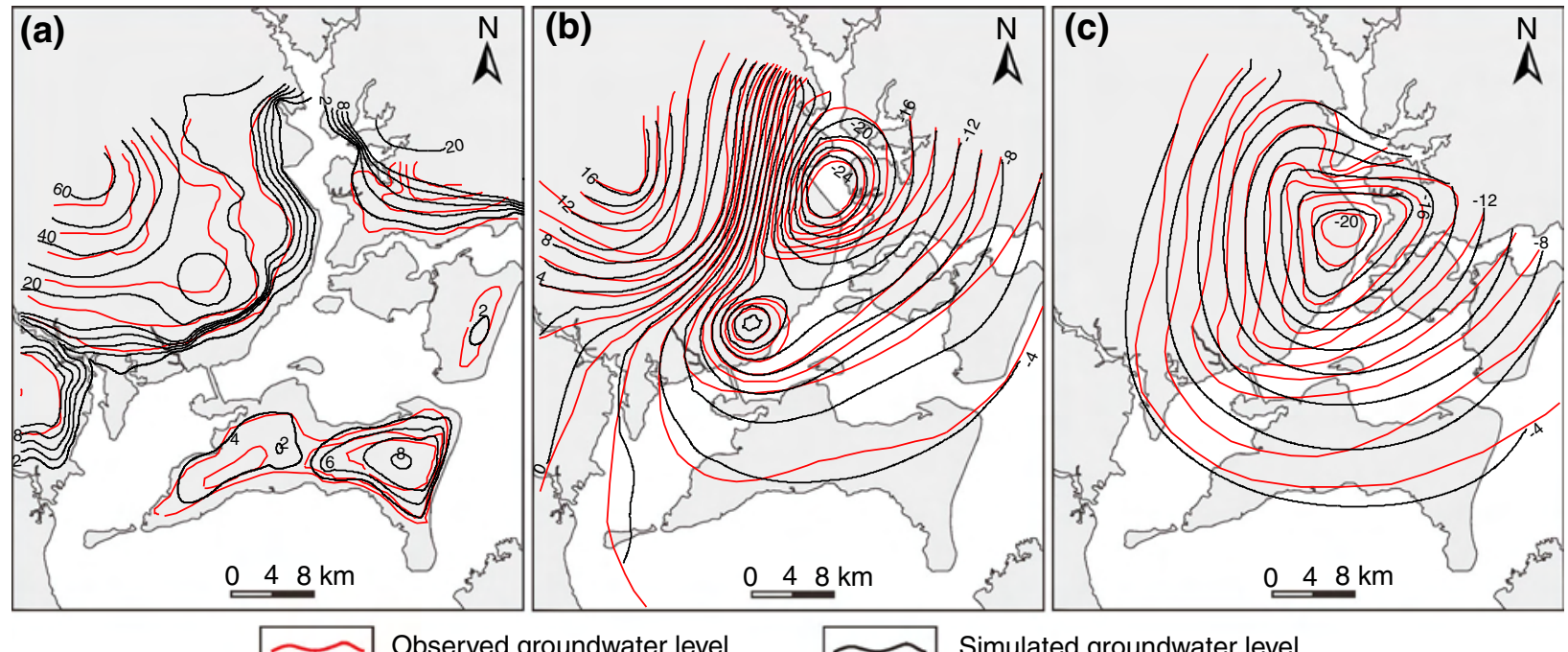

$\sim$ Observed groundwater level
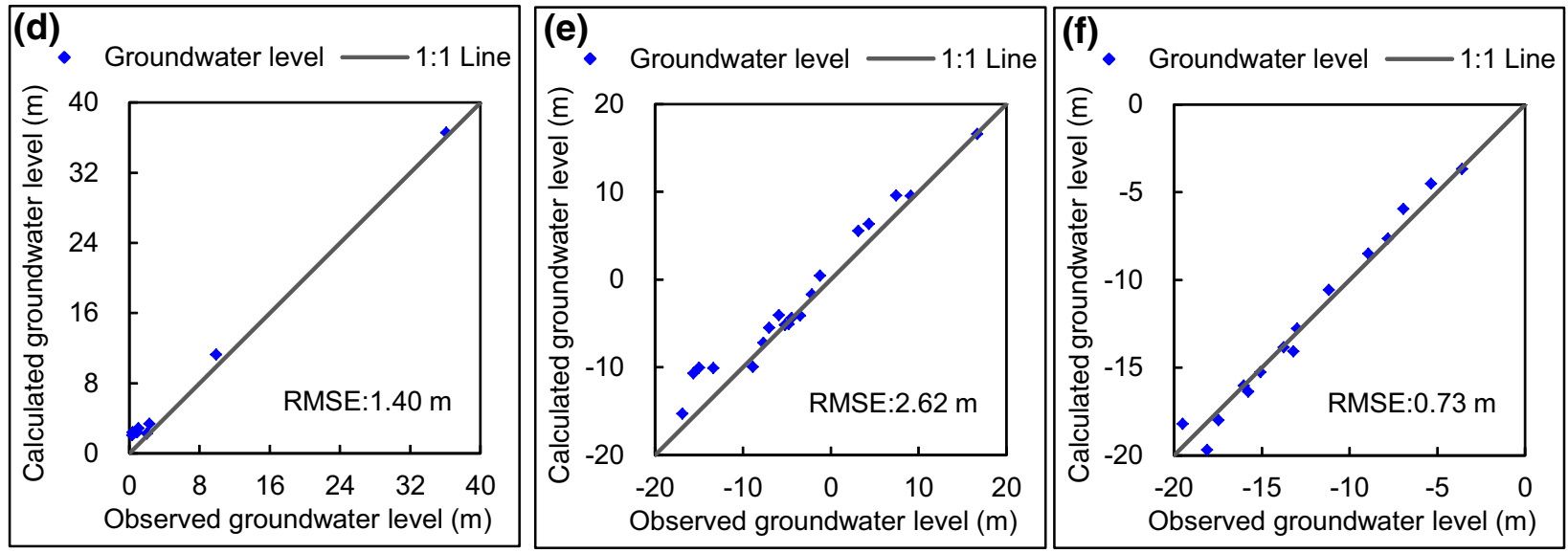

Figure 9. Calibration maps obtained for steady-state conditions. (a) Comparison of observed (red line) and calculated (black line) groundwater level of the shallow unconfined aquifer; (b) comparison of observed and calculated groundwater level of the middle confined aquifer; (c) comparison of observed and calculated groundwater level of the deep confined aquifer; (d) groundwater level calibration curve of the shallow unconfined aquifer; (e) groundwater level calibration curve of the middle confined aquifer; and (f) groundwater level calibration curve of the deep confined aquifer.

groundwater budget are shown in figure 11. In these four years, the aquifer system showed a negative balance of approximately $3826 \times 10^{4}$ to $4502 \times 10^{4} \mathrm{~m}^{3} / \mathrm{a}$ (figure 11). The negative balance value increases year by year. This is mainly because of decreasing precipitation (figure 7) and generally increasing pumping rate from 2008 to 2011.

\section{Results and discussion}

Using the calibrated model, groundwater sustainability was assessed by evaluating the response of the groundwater sustainability indicators (including NHPA of the unconfined aquifer, and groundwater level dynamic and flow velocities of the offshore boundaries of the confined aquifers) to different mean sea level rise (MSLR), pumping rates and groundwater exploitation schemes (i.e., adjustment of the groundwater source fields) scenarios. All the simulation scenarios started from January 2012 and lasted for 4 years. The simulated results of these scenarios were compared to those obtained from the calibrated model (i.e., the base model) representing the groundwater flow of 2011 (scenario A).

\subsection{Impact of the mean sea level rise}

It is unequivocal that the global average sea level will rise in the future (Lemieux et al. 2015). Therefore, the mean sea level rise (MSLR) was considered as an important consideration in this paper for analyzing seawater intrusion risk. Two simulation 

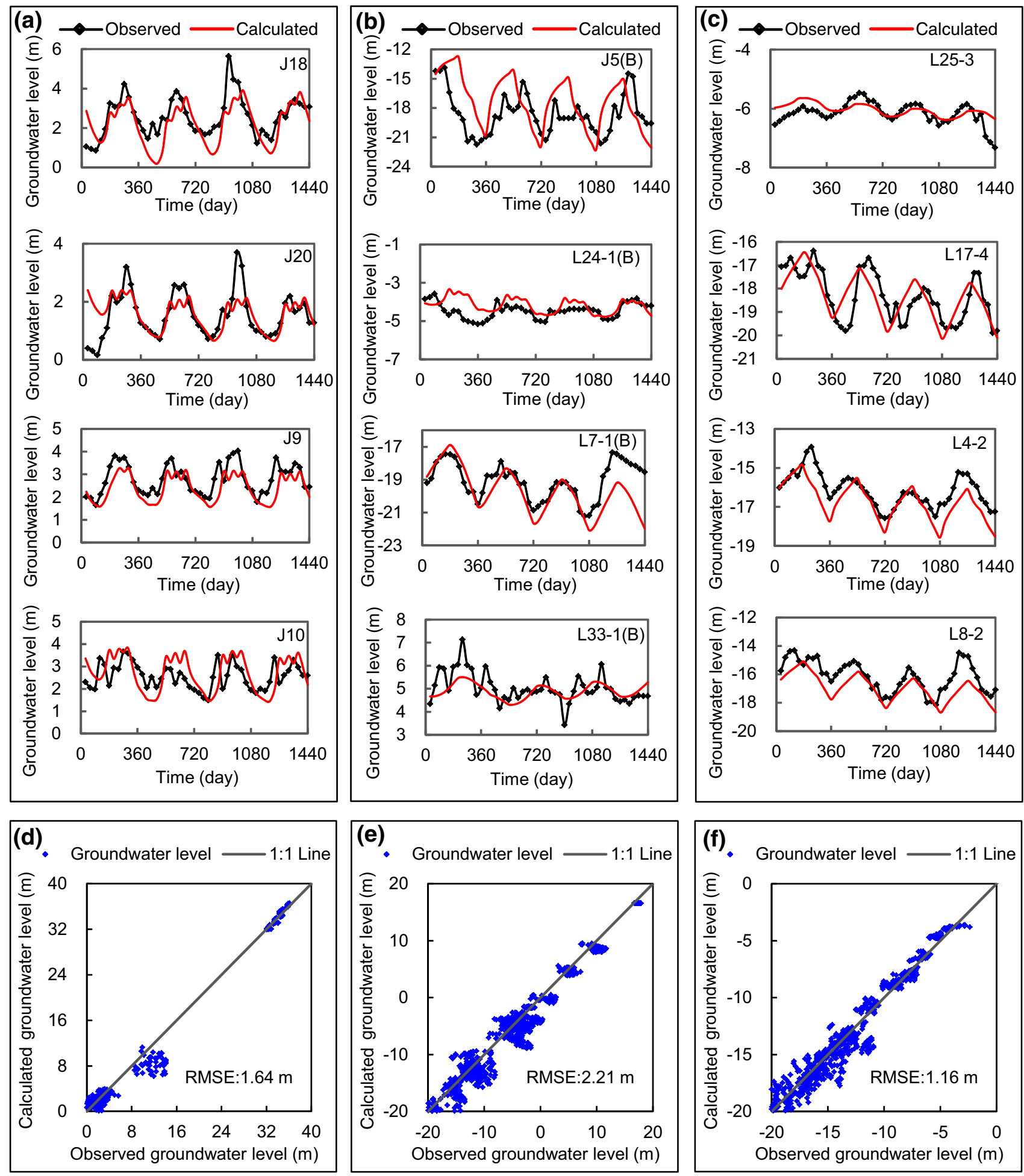

Figure 10. Calibration maps obtained for transient-state conditions. (a) Time series graph of observed vs. calculated groundwater levels for several observation wells of the shallow unconfined aquifer; (b) time series graph of observed vs. calculated groundwater levels for several observation wells of the middle confined aquifer; (c) time series graph of observed vs. calculated groundwater levels for several observation wells of the deep confined aquifer; (d) calibration curve of all spatial and temporal groundwater levels data of the shallow unconfined aquifer; (e) calibration curve of all spatial and temporal groundwater level data of the middle confined aquifer; and (f) calibration curve of all spatial and temporal groundwater levels data of the deep confined aquifer. 


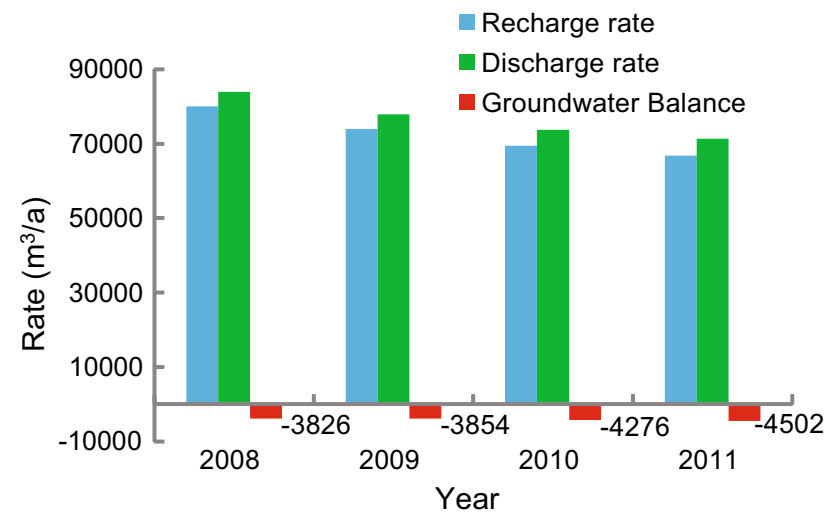

Figure 11. Groundwater budgets (1 January 2008-30 December 2011) under transient conditions.

scenarios of different MSLR were designed: MSLR of $0.5 \mathrm{~m}$ (scenario 1B) and MSLR of $1.0 \mathrm{~m}$ (scenario $1 \mathrm{C}$ ). In these scenarios, the parameters were kept the same as the calibrated model (scenario A), the calibrated groundwater flow on December 2011 was used as the initial condition, and the boundary conditions affected by the MSLR were updated.

The forecasting results of the MSLR scenarios are shown in figure 12 which display the changes of the NHPA in the unconfined aquifer. In figure 12 , the red area is the measured saline unconfined groundwater area induced by NHPA during 2010; the trapped area by the blue line represents the simulated NHPA under the current mean sea level condition (scenario A). By comparison, the simulated NHPA is basically consistent with the investigated result. However, the simulated NHPA is larger than the investigated result, especially in Nansan Island. This difference between the simulated and investigated results is mainly related to the low-accuracy terrain data of the coastal area in the model.

The simulated results of scenarios $1 \mathrm{~B}$ and $1 \mathrm{C}$ indicate that NHPA will increase with the MSLR (figure 12). Compared to the simulated NHPA $\left(188.84 \mathrm{~km}^{2}\right)$ in the base model, when the mean sea level rises by $0.5 \mathrm{~m}$ (scenario $1 \mathrm{~B}$ ), the NHPA increases landward by $26.86-215.70 \mathrm{~km}^{2}$; when the mean sea level rises by $1.0 \mathrm{~m}$ (scenario $1 \mathrm{C}$ ), the NHPA increases landward by $53.35-242.19 \mathrm{~km}^{2}$. Because the NHPA can represent the area vulnerable to seawater intrusion, the shallow unconfined groundwater resources in regions with larger NHPA should be protected. Thus, according to the simulated results, to avoid seawater intrusion, we suggest that the coastal unconfined groundwater,

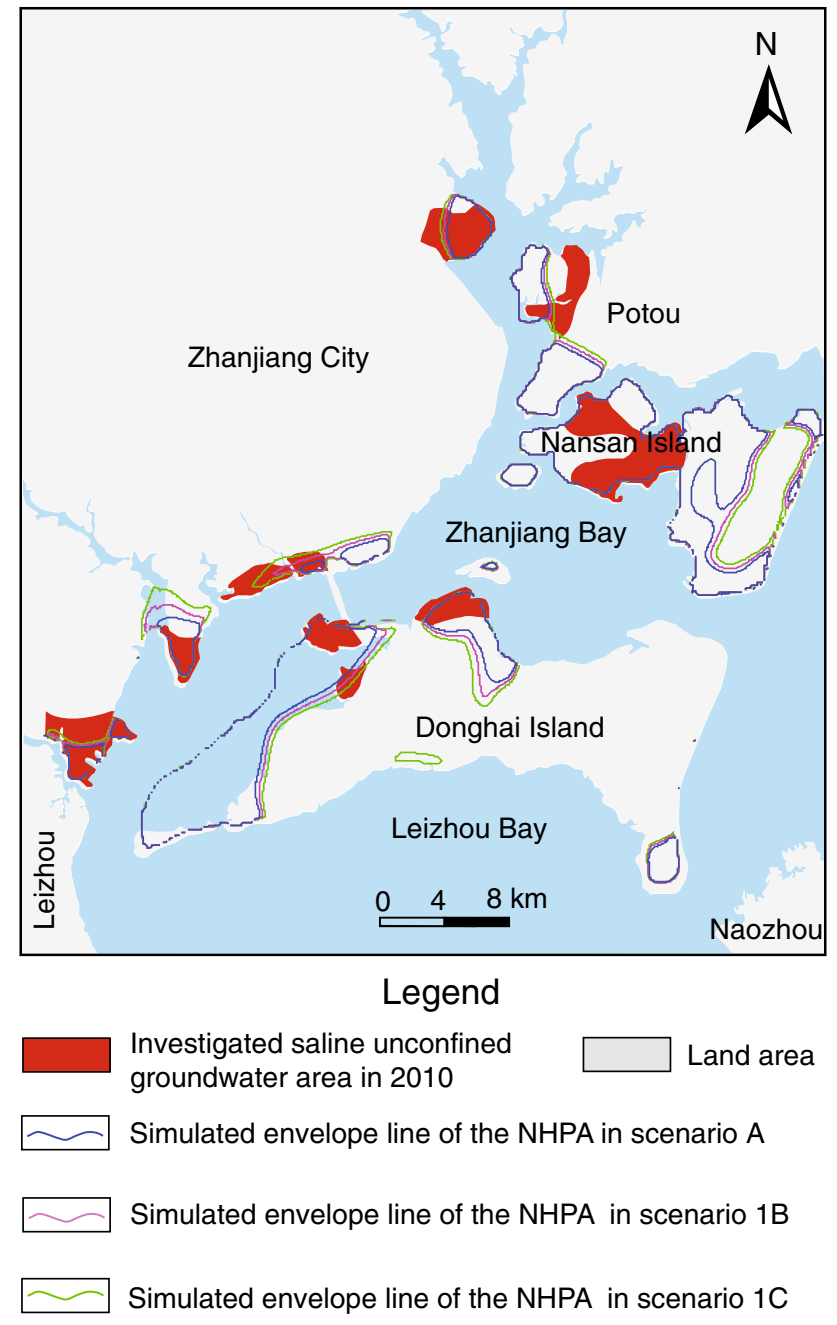

Figure 12. Changes of negative hydraulic pressure area (NHPA) in the unconfined aquifer under different mean sea level rise conditions.

especially in Nansan Island, should not be exploited.

In addition, for the confined aquifers, the groundwater level dynamics and recharge flow velocities of the offshore boundaries were analyzed to assess the MSLR effects on seawater intrusion risk. In this modelling forecasting, to obtain data of groundwater level dynamics and recharge flow velocities, four observation wells (BW03/MC, BW03/DC, BW05/MC and BW05/DC) were assigned near the offshore boundaries (figure 5). Wells BW03/MC and BW03/DC were designed near the southern lateral recharge boundaries of the middle and deep confined aquifers respectively. Wells BW05/MC and BW05/DC were designed near the eastern lateral recharge boundaries (figure 5). The results (figure 13) show that groundwater level dynamics maintain a similar pattern under different 
MSLR conditions, but the mean groundwater levels increases with the rising sea level. This increase of the mean groundwater level is due to the tidal loading effect which is a non-negligible factor on coastal confined groundwater dynamics (Chuang and Yeh
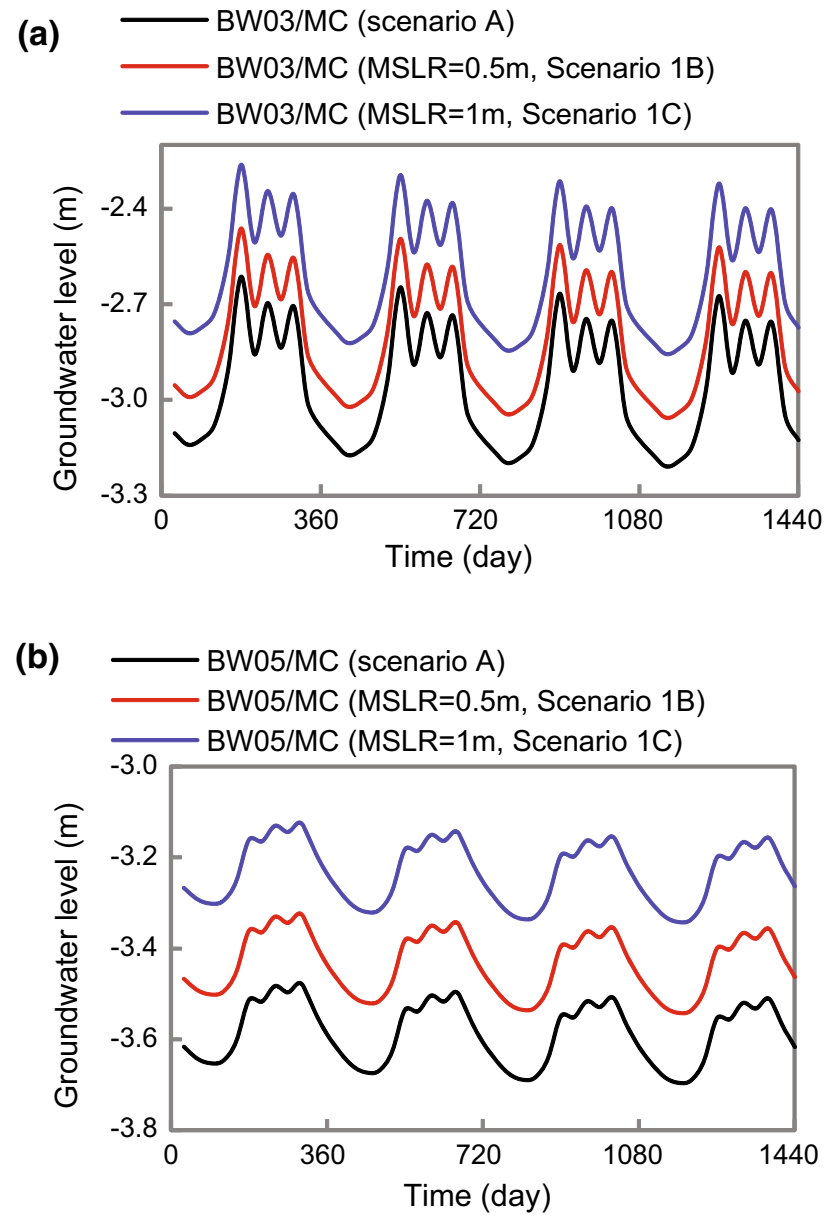

Figure 13. Groundwater level dynamics of the offshore recharge boundary of the middle confined aquifer under different mean sea level rise conditions. (a) Observation well BW03/MC and (b) observation well BW05/MC.
2007; Wang et al. 2012; Zhou et al. 2016). Moreover, the recharge flow velocities of the offshore boundaries are displayed in table 3. As shown, when the mean sea level rises by $0.5 \mathrm{~m}$, the offshore recharge flow velocities of the middle and deep confined aquifers increase by $12-15 \%$ and 8-9\%, respectively. When the mean sea level rises by $1 \mathrm{~m}$, the recharge flow velocities increase by $17-$ $20 \%$ and $11-13 \%$. These results indicate that the MSLR can result in greater landward recharge flux, which is a major factor in reflecting seawater intrusion risk for the confined aquifers.

\subsection{Impact of the groundwater exploitation amount}

Hydrogeological investigation shows that the confined groundwater level dynamics present a declining trend, especially the deep confined groundwater (First Hydrogeological Team 2009b-2012). The groundwater exploitation amount is the major factor influencing this declining trend. In this section, numerical forecasting scenarios with different withdrawal rates were conducted to assess the sustainable yield of the aquifer system. Four exploitation scenarios were designed: withdrawal decreasing by 10\% (scenario 2B); withdrawal decreasing by $20 \%$ (scenario $2 \mathrm{C}$ ); withdrawal increasing by $20 \%$ (scenario 2D); and withdrawal increasing by $50 \%$ (scenario 2E). The simulated results of the scenarios $2 \mathrm{~B}-2 \mathrm{E}$ were compared with that of the base model (scenario A).

Figure 14 shows the NHPA changes under different withdrawal scenarios. Figure 14 reveals that there is an increase in trend of NHPA with increasing groundwater exploitation amount. Compared the NHPA of the base model $\left(188.84 \mathrm{~km}^{2}\right)$, the simulated NHPA of scenario $2 \mathrm{C}$ decreased

Table 3. Values of offshore recharge flow velocity in scenarios with different MSLR and their percentage changes relative to the velocity of the base model.

\begin{tabular}{|c|c|c|c|c|c|c|}
\hline \multirow[b]{2}{*}{ Boundary wells } & & \multicolumn{3}{|c|}{ Offshore recharge flow velocity $(\mathrm{m} / \mathrm{d})$} & \multicolumn{2}{|c|}{$\begin{array}{l}\text { Percentage change in offshore } \\
\text { recharge flow velocity relative to } \\
\text { that of the base model }\end{array}$} \\
\hline & & $\begin{array}{c}\text { Base model } \\
(\text { Scenario A) }\end{array}$ & $\begin{array}{l}\text { MSLR }=0.5 \mathrm{~m} \\
(\text { Scenario } 1 \mathrm{~B})\end{array}$ & $\begin{array}{c}\text { MSLR }=1 \mathrm{~m} \\
(\text { Scenario } 1 \mathrm{C})\end{array}$ & $\begin{array}{l}\text { MSLR }=0.5 \mathrm{~m} \\
(\text { Scenario } 1 \mathrm{~B})\end{array}$ & $\begin{array}{c}\text { MSLR }=1 \mathrm{~m} \\
(\text { Scenario } 1 \mathrm{C})\end{array}$ \\
\hline \multirow{2}{*}{$\begin{array}{l}\text { Middle confined } \\
\text { aquifer }\end{array}$} & BW03/MC & 0.0065 & 0.0073 & 0.0076 & $12 \%$ & $17 \%$ \\
\hline & $\mathrm{BW} 05 / \mathrm{MC}$ & 0.0040 & 0.0046 & 0.0048 & $15 \%$ & $20 \%$ \\
\hline \multirow{2}{*}{$\begin{array}{l}\text { Deep confined } \\
\text { aquifer }\end{array}$} & BW03/DC & 0.0129 & 0.0139 & 0.0143 & $8 \%$ & $11 \%$ \\
\hline & BW05/DC & 0.0109 & 0.0119 & 0.0123 & $9 \%$ & $13 \%$ \\
\hline
\end{tabular}




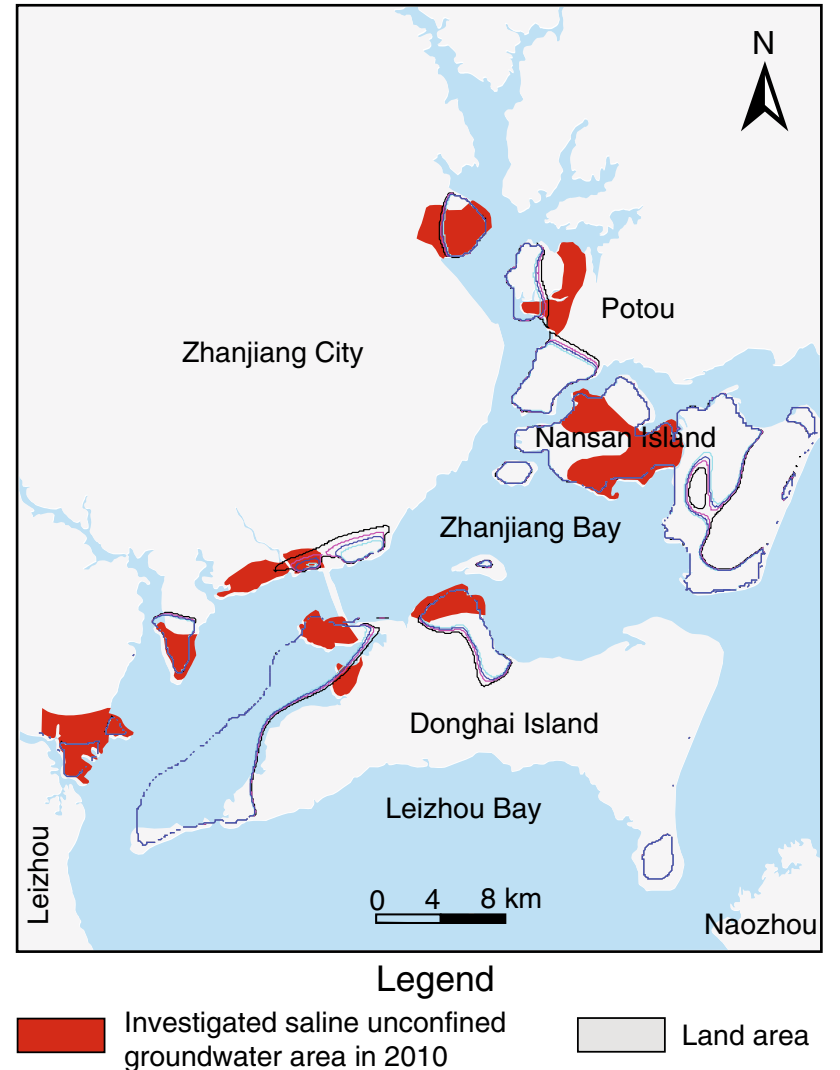

$\sim$ Simulated envelope line of the NHPA in scenario A

$\Longrightarrow$ Simulated envelope line of the NHPA in scenario $2 \mathrm{C}$

$\sim$ Simulated envelope line of the NHPA in scenario 2D

Simulated envelope line of the NHPA in scenario $2 \mathrm{E}$

Figure 14. Changes of negative hydraulic pressure area (NHPA) in the unconfined aquifer with different groundwater exploitation rates.

by $5.36-183.48 \mathrm{~km}^{2}$; the simulated NHPA of scenario $2 \mathrm{D}$ increased by $7.17-196.01 \mathrm{~km}^{2}$; and the simulated NHPA of scenario $2 \mathrm{E}$ increased by $13.48-202.32 \mathrm{~km}^{2}$. According to this result, it can be concluded that the local groundwater exploitation amount should not increase in the future, and decreasing the groundwater exploitation amount properly could be an effective way for reducing seawater intrusion risk into the unconfined aquifer. In the next paragraph, the groundwater level dynamic and recharge flow velocity of the offshore boundaries of the confined aquifers were evaluated to quantitatively determine the sustainable yield.

Figure 15 illustrates the groundwater level dynamics of the offshore boundaries under various withdrawal scenarios. As shown in figure 15, with decreasing groundwater extraction amount, the groundwater level presents a gradually rising trend (scenario $2 \mathrm{C}$ ), which is more marked in the southern recharge boundary (about $+0.14 \mathrm{~m}$ in wells BW03/MC and BW03/DC) and less marked for the eastern recharge boundary (about +0.07 $\mathrm{m}$ in wells BW05/MC and BW05/DC). It can be concluded that the declining trend of the confined groundwater level of the offshore recharge boundaries can be controlled when the groundwater extraction amount is decreased by $20 \%$. This result indicates that $80 \%$ of the current groundwater extraction amount should be sustainable $\left(1.784 \times 10^{8} \mathrm{~m}^{3} / \mathrm{a}\right)$.

In addition, the simulated recharge flow velocities of the offshore boundaries are displayed in table 4. As shown, when decreasing the groundwater withdrawal by $20 \%$, the offshore recharge flow velocities of the middle and deep confined aquifers can decrease by $15 \%$ and $10-13 \%$, respectively; however, when increasing the groundwater withdrawal, the offshore recharge flow velocities of the confined aquifers can significantly increase. This result also confirms that decreasing groundwater withdrawal by $20 \%$ is an effective way to reduce seawater intrusion risk into the confined aquifers, and a groundwater exploitation amount of $1.784 \times 10^{8} \mathrm{~m}^{3} / \mathrm{a}$ is sustainable.

\subsection{Impact of groundwater supply schemes}

As concluded in the previous section, the local groundwater exploitation amount should be decreased by $20 \%$ to meet sustainability goals. To guarantee adequate public water demand, the decreased 20\% groundwater should be offset by the surface water resources. However, water from the existing surface water supply system is sufficient only to satisfy the needs of agricultural irrigation (First Hydrogeological Team 2009b-2012). For this reason, the groundwater exploitation scheme must be adjusted. According to groundwater resource fields planning (figure 1), we know that, apart from used groundwater resource fields (i.e., Chikan, Xiashan, Puzai and Potou), there are two unused groundwater resource fields (i.e., Taiping and Donghai Island) that can be developed. In this study, we proposed that the decreased $20 \%$ groundwater supply is offset by the Taiping or Donghai Island groundwater resource field. To discuss the reasonability and sustainability of this proposed scheme, two simulation scenarios were designed based on groundwater supplied by the Taiping groundwater 

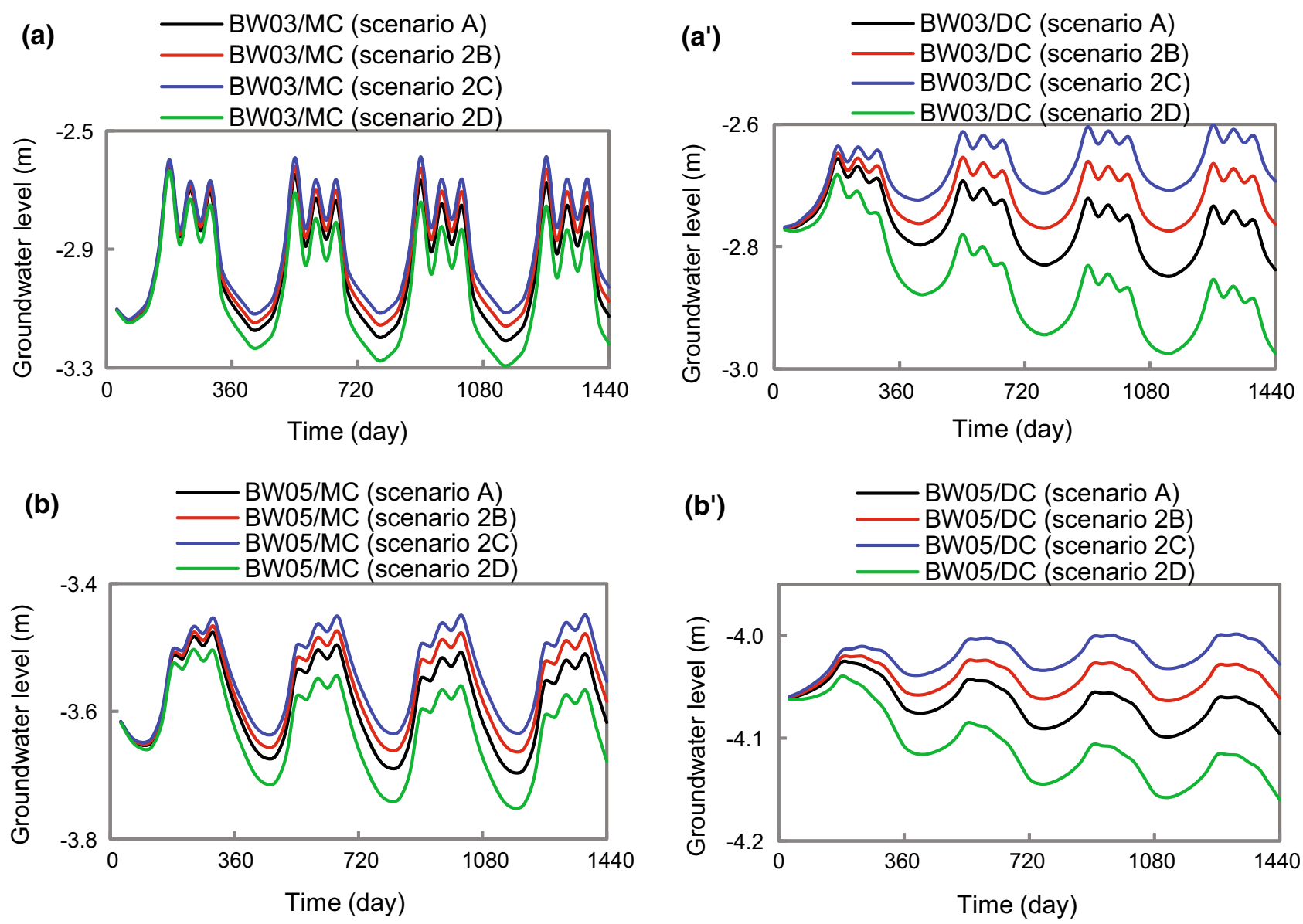

Figure 15. Groundwater level dynamics of the offshore recharge boundary of the confined aquifers with different groundwater exploitation rates. (a) Observation well BW03/MC for middle confined aquifer; (b) observation well BW05/MC for middle confined aquifer; $\left(\mathbf{a}^{\prime}\right)$ observation well BW03/DC for deep confined aquifer; and ( $\left.\mathbf{b}^{\prime}\right)$ observation well BW05/DC for deep confined aquifer.

resource field (scenario 3B) and by the Donghai Island groundwater resource field (scenario $3 \mathrm{C}$ ). The simulated results of NHPA, groundwater level dynamics and flow velocities in each scenario are compared to those in the base model (scenario A).

Figure 16 illustrates the NHPA changes under different groundwater supply schemes. When the decreased $20 \%$ groundwater withdrawal is supplied by Donghai Island, the NHPA in the whole model domain increases by $6.44 \mathrm{~km}^{2}$, of which the NHPA in Donghai Island increases by $8.16 \mathrm{~km}^{2}$ and NHPA in the other regions decreases by 1.72 $\mathrm{km}^{2}$. When the decreased $20 \%$ groundwater is supplied by Taiping, the NHPA decreases by $3.38 \mathrm{~km}^{2}$, of which the NHPA in Taiping increases by only $0.58 \mathrm{~km}^{2}$ and NHPA in the other regions decreases by $3.96 \mathrm{~km}^{2}$. By comparing the NHPA results under different groundwater supply schemes, it can be concluded that using groundwater from the Taiping groundwater resource field is reasonable to offset decreased groundwater usage from the currently used groundwater resource fields.

Moreover, the groundwater level dynamics of the offshore recharge boundaries under different groundwater supply schemes were analyzed to further demonstrate the sustainability of the proposed groundwater supply scheme based on the Taiping groundwater resource field. Figure 17 shows the groundwater level dynamics of the offshore recharge boundaries under different groundwater supply schemes. By comparing the blue and black curves in figure 17, we notice that, when the decreased $20 \%$ groundwater exploitation amount is supplied by Donghai Island, there is a general decreasing trend in confined groundwater level of the offshore recharge boundaries, which is more marked for the southern recharge boundary (approximately -0.48 and $-0.59 \mathrm{~m}$ in wells BW03/MC and BW03/DC, respectively) and less marked for the eastern recharge boundary (approximately -0.13 and $-0.11 \mathrm{~m}$ in wells BW05/ 

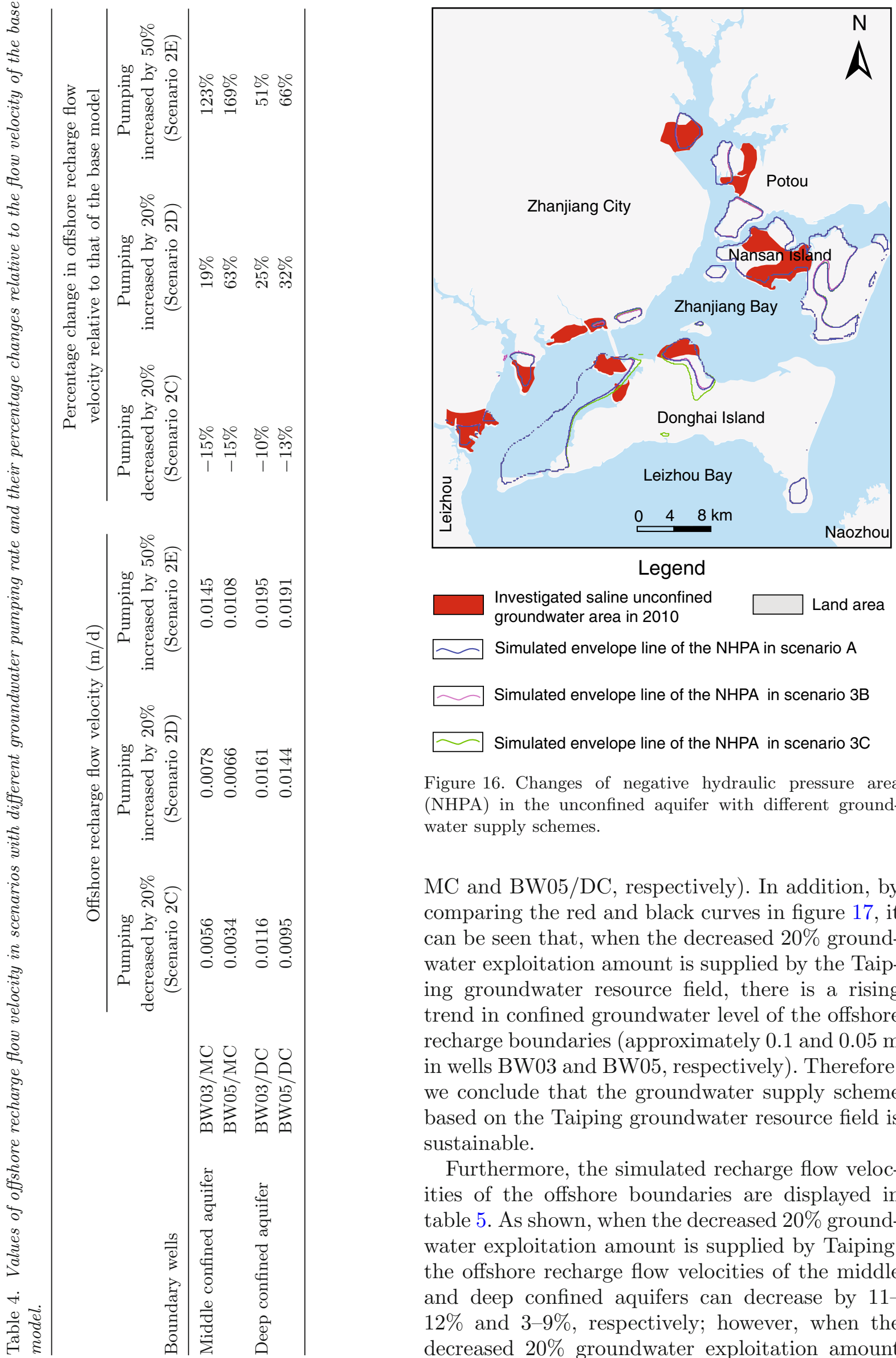

Figure 16. Changes of negative hydraulic pressure area (NHPA) in the unconfined aquifer with different groundwater supply schemes.

$\mathrm{MC}$ and BW05/DC, respectively). In addition, by comparing the red and black curves in figure 17, it can be seen that, when the decreased $20 \%$ groundwater exploitation amount is supplied by the Taiping groundwater resource field, there is a rising trend in confined groundwater level of the offshore recharge boundaries (approximately 0.1 and $0.05 \mathrm{~m}$ in wells BW03 and BW05, respectively). Therefore, we conclude that the groundwater supply scheme based on the Taiping groundwater resource field is sustainable.

Furthermore, the simulated recharge flow velocities of the offshore boundaries are displayed in table 5 . As shown, when the decreased $20 \%$ groundwater exploitation amount is supplied by Taiping, the offshore recharge flow velocities of the middle and deep confined aquifers can decrease by 11$12 \%$ and $3-9 \%$, respectively; however, when the decreased $20 \%$ groundwater exploitation amount 

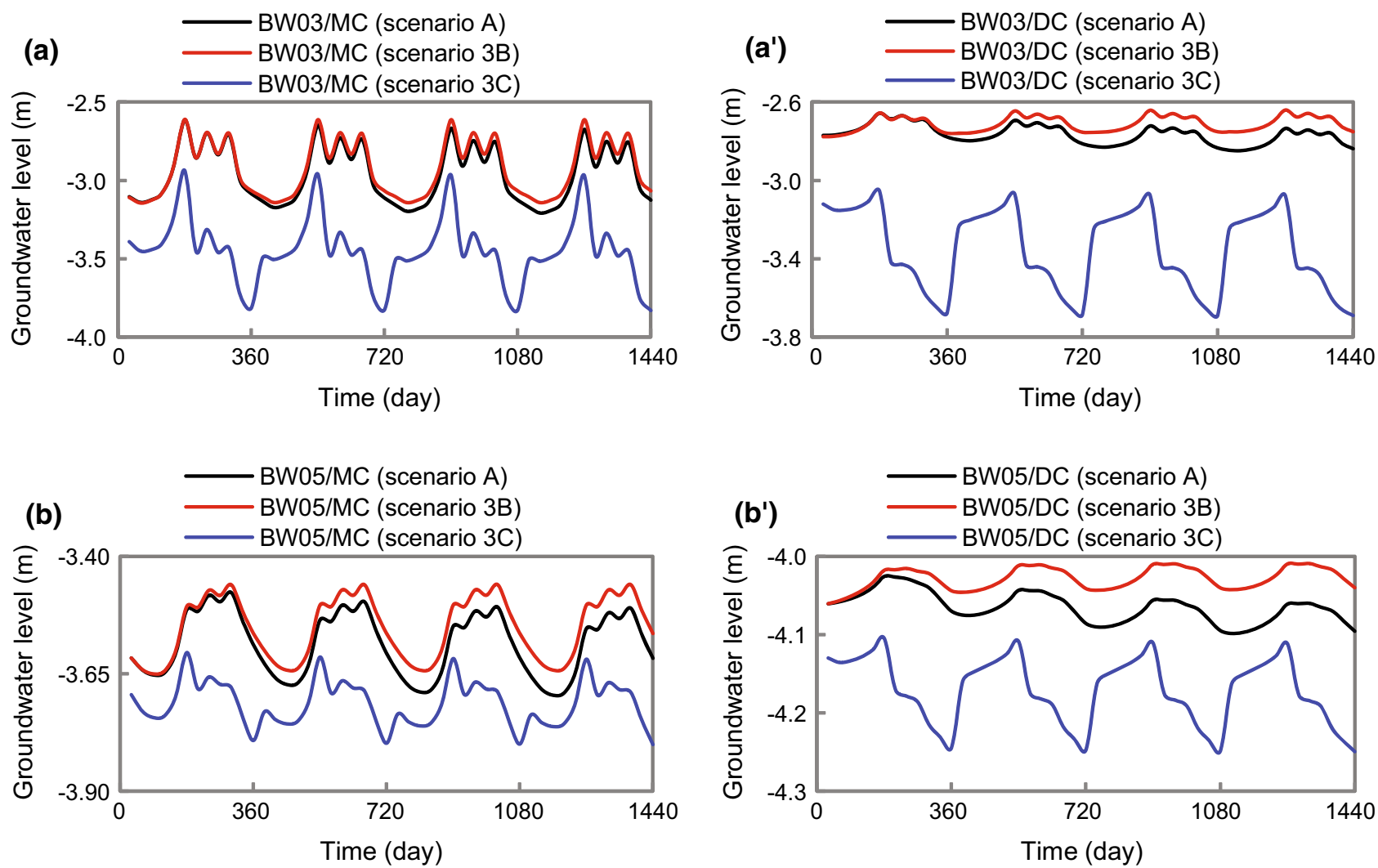

Figure 17. Groundwater level dynamics of the lateral recharge boundary of the confined aquifers with different groundwater supply schemes. (a) Observation well BW03/MC for middle confined aquifer; (b) observation well BW05/MC for middle confined aquifer; ( $\left.\mathbf{a}^{\prime}\right)$ observation well BW03/DC for deep confined aquifer; $\left(\mathbf{b}^{\prime}\right)$ observation well BW05/DC for deep confined aquifer.

Table 5. Values of offshore recharge flow velocity in scenarios with different groundwater supply schemes and their percentage changes relative to the velocity of the base model.

\begin{tabular}{|c|c|c|c|c|c|}
\hline \multirow[b]{2}{*}{ Boundary well } & & \multicolumn{2}{|c|}{ Offshore recharge flow velocity $(\mathrm{m} / \mathrm{d})$} & \multicolumn{2}{|c|}{$\begin{array}{l}\text { Percentage change in offshore recharge flow } \\
\text { velocity relative to the velocity of the base model }\end{array}$} \\
\hline & & $\begin{array}{l}\text { GWRF-Taiping } \\
\text { (Scenario 3B) }\end{array}$ & $\begin{array}{l}\text { GWRF-Donghai } \\
\text { Island } \\
\text { (Scenario 3C) }\end{array}$ & $\begin{array}{r}\text { GWRF-Taiping } \\
(\text { Scenario 3B) }\end{array}$ & $\begin{array}{l}\text { GWRF-Donghai } \\
\text { Island } \\
\text { (Scenario 3C) }\end{array}$ \\
\hline $\begin{array}{l}\text { Middle confined } \\
\text { aquifer }\end{array}$ & $\begin{array}{l}\mathrm{BW} 03 / \mathrm{MC} \\
\mathrm{BW} 55 / \mathrm{MC}\end{array}$ & $\begin{array}{l}0.0057 \\
0.0036\end{array}$ & $\begin{array}{l}0.0268 \\
0.0092\end{array}$ & $\begin{array}{l}-12 \% \\
-11 \%\end{array}$ & $\begin{array}{l}311 \% \\
128 \%\end{array}$ \\
\hline $\begin{array}{l}\text { Deep confined } \\
\text { aquifer }\end{array}$ & $\begin{array}{l}\mathrm{BW} 03 / \mathrm{DC} \\
\mathrm{BW} 05 / \mathrm{DC}\end{array}$ & $\begin{array}{l}0.0125 \\
0.0099\end{array}$ & $\begin{array}{l}0.0233 \\
0.0156\end{array}$ & $\begin{array}{l}-3 \% \\
-9 \%\end{array}$ & $\begin{array}{l}81 \% \\
43 \%\end{array}$ \\
\hline
\end{tabular}

is supplied by Donghai Island, the recharge flow velocities of the offshore boundaries will significantly increase. This result confirms that the groundwater supply scheme based on the Taiping groundwater resource field can mitigate of seawater intrusion risk into the confined aqui fers.

In summary, our proposed groundwater supply scheme of jointly using current and Taiping groundwater resources fields can not only satisfy the public groundwater demands but also protect the groundwater resources.

\section{Conclusions}

Sustainability of the coastal groundwater resources in Zhanjiang city has been a critical issue as pumping-induced groundwater level drawdown has become more evident. To assess the groundwater 
sustainability of Zhanjiang, a numerical groundwater flow model was developed in this study. The transient modelling results reveal that the coastal groundwater was overexploited with a negative groundwater budget $\left(-3826 \times 10^{4}\right.$ to $-4502 \times$ $\left.10^{4} \mathrm{~m}^{3} / \mathrm{a}\right)$. The simulated results indicate that, under the situations of current groundwater exploitation scheme and mean sea level rise, seawater intrusion risk will be increased in the future, especially for the unconfined groundwater in coastal area and Nansan Island. The unconfined groundwater in the coastal area and Nansan Island should not be exploited in future. In addition, the groundwater level drawdown trend can be controlled when the groundwater exploiting amount is decreased by $20 \%$, and the sustainable exploitation amount for Zhanjiang is $1.784 \times 10^{8} \mathrm{~m}^{3} / \mathrm{a}$ (i.e., $80 \%$ of the current exploitation amount). To satisfy current public water demands, the decreased $20 \%$ groundwater exploitation amount can be supplied by the Taiping groundwater resource field. Joint use of the current and Taiping groundwater resources fields can be an effective groundwater exploitation scheme for sustainable groundwater management for Zhanjiang city.

\section{Acknowledgements}

We are grateful to the anonymous reviewers for their thoughtful comments. Our research was supported by the National Natural Science Foundation of China (Grant No. 41502255).

\section{References}

Alfaro P, Liesch T and Goldscheider N 2017 Modelling groundwater over-extraction in the southern Jordan Valley with scarce data; Hydrogeol. J. 25(5) 1319-1340, doi: $10.1007 / \mathrm{s} 10040-017-1535-\mathrm{y}$.

Alley W M and Leake S A 2004 The journey from safe yield to sustainability; Groundwater 42 12-16.

Ayvaz M T and Karahan H 2008 A simulation/optimization model for the identification of unknown groundwater well locations and pumping rates; J. Hydrol. 357 76-92.

Barazzuoli P, Nocchi M, Rigati R and Salleolini M 2008 A conceptual and numerical model for groundwater management: A case study on a coastal aquifer in southern Tuscany; Hydrogeol. J. 16 1557-1576.

Barlow P M and Reichard E G 2010 Saltwater intrusion in coastal regions of North America; Hydrogeol. J. 18 247260.

Chandio A S, Lee T S and Mirjat M S 2012 The extent of waterlogging in the lower Indus Basin (Pakistan) - A modeling study of groundwater levels; J. Hydrol. 426-427 103-111.

Chuang M-H and Yeh H-D 2007 An analytical solution for the head distribution in a tidal leaky confined aquifer extending an infinite distance under the sea; Adv. Water Resour. 30 439-445.

De Filippis G, Foglia L, Giudici M, Mehl S, Margiotta S and Negri S L 2016 Seawater intrusion in karstic, coastal aquifers: Current challenges and future scenarios in the Taranto area (southern Italy); Sci. Total Environ. 573 1340-1351.

Dogrul E C, Kadir T N, Brush C F and Chung F I 2016 Linking groundwater simulation and reservoir system analysis models: The case for California's Central Valley; Environ. Model. Softw. 77 168-182.

El-Kadi AI, Tillery S, Whittier R B, Hagedorn B, Mair A, Ha K and Koh G-W 2014 Assessing sustainability of groundwater resources on Jeju Island, South Korea, under climate change, drought, and increased usage; Hydrogeol. J. 22 625-642.

Eshtawi T, Evers M, Tischbein B and Diekkrüger B 2016 Integrated hydrologic modeling as a key for sustainable urban water resources planning; Water Res. 101 411-428.

Ferguson G and Gleeson T 2012 Vulnerability of coastal aquifers to climate change and groundwater use; Nat. Clim. Change 2 342-345.

First Hydrogeological Team, Guangdong Geological Bureau 2009a Report of regional hydrogeologic investigation of Donghai island (in Chinese).

First Hydrogeological Team, Guangdong Geological Bureau 2009b Monitoring report of the groundwater dynamics of Zhanjiang city in 2008 (in Chinese).

First Hydrogeological Team, Guangdong Geological Bureau 2010 Monitoring report of the groundwater dynamics of Zhanjiang city in 2009 (in Chinese).

First Hydrogeological Team, Guangdong Geological Bureau 2011 Monitoring report of the groundwater dynamics of Zhanjiang city in 2010 (in Chinese).

First Hydrogeological Team, Guangdong Geological Bureau 2012 Monitoring report of the groundwater dynamics of Zhanjiang city in 2011 (in Chinese).

Ghassemi F, Close A and Kellett J R 1997 Numerical models for the management of land and water resources salinization; Math. Comput. Simulat. 43 323-329.

Gleeson T, Alley W M, Allen D M, Sophocleous M A, Zhou Y, Taniguchi M and VanderSteen J 2012 Towards sustainable groundwater use: Setting long-term goals, backcasting, and managing adaptively; Groundwater $\mathbf{5 0}$ 19-26.

Green N R and MacQuarrie K T B 2014 An evaluation of the relative importance of the effects of climate change and groundwater extraction on seawater intrusion in coastal aquifers in Atlantic Canada; Hydrogeol. J. 22 609-623.

Heydari F, Saghafian B and Delavar M 2016 Coupled quantity-quality simulation-optimization model for conjunctive surface-groundwater use; Water Resour. Manag. 30 4381-4397

Jang C S, Chen C F, Liang C P and Chen J S 2016 Combining groundwater quality analysis and a numerical flow simulation for spatially establishing utilization strategies for groundwater and surface water in the Pingtung Plain; J. Hydrol. 533 541-556. 
Jhorar R K, Smit A A M F R and Roest C W J 2009 Assessment of alternative water management options for irrigated agriculture; Agric. Water Manag. 96 975-981.

Kalf F R P and Woolley D R 2005 Applicability and methodology of determining sustainable yield in groundwater systems; Hydrogeol. J. 13 295-312.

Knowling M J, Werner A D and Herckenrath D 2015 Quantifying climate and pumping contributions to aquifer depletion using a highly parameterised groundwater model: Uley South Basin (South Australia); J. Hydrol. 523 $515-530$

Kourakos G and Mantoglou A 2011 Simulation and multiobjective management of coastal aquifers in semi-arid regions; Water Resour. Manag. 25(4) 1063-1074.

Kourakos G and Mantoglou A 2013 Development of a multiobjective optimization algorithm using surrogate models for coastal aquifer management; J. Hydrol. 479 13-23.

Lathashri U A and Mahesha A 2016 Groundwater sustainability assessment in coastal aquifers; J. Earth Syst. Sci. 125 1103-1118.

Lemieux J-M, Hassaoui J, Molson J, Therrien R, Therrien P, Chouteau M and Ouellet M 2015 Simulating the impact of climate change on the groundwater resources of the Magdalen Islands, Québec, Canada; J. Hydrol. 3 400-423.

Lu W, Yang Q, Martin J D and Juncosa R 2013 Numerical modelling of seawater intrusion in Shenzhen (China) using a 3D density-dependent model including tidal effects; J. Earth Syst. Sci. 122 451-465.

Luo Q and Su Z H 2007 The characteristic analysis and the prevention and control methods from the sea water invasion in Naozhou island; J. Geol. Hazard Environ. Preserv. 18 28-32 (in Chinese).

Maimone M 2004 Defining and managing sustainable yield; Groundwater 42 809-814.

Mehdizadeh S S, Karamalipour S E and Asoodeh R 2017 Sea level rise effect on seawater intrusion into layered coastal aquifers (simulation using dispersive and sharp-interface approaches); Ocean Coast. Manag. 138 11-18.

Narayan K A, Schleeberger C and Bristow K L 2007 Modelling seawater intrusion in the Burdekin delta irrigation area, North Queensland, Australia; Agríc. Water Manag. $89217-228$.

Nocchi M and Salleolini M 2013 A 3D density-dependent model for assessment and optimization of water management policy in a coastal carbonate aquifer exploited for water supply and fish farming; J. Hydrol. 492 200-218.

Paniconi C, Khlaifi I, Lecca G, Giacomelli A and Tarhouni J 2001 Modeling and analysis of seawater intrusion in the coastal aquifer of eastern Cap-Bon, Tunisia; Transport Porous Med. 43 3-28.

Pongkijvorasin S, Roumasset J, Duarte T K and Burnett K 2010 Renewable resource management with stock externalities: Coastal aquifers and submarine groundwater discharge; Resour. Energy Econ. 32 277-291.

Rejani R, Jha M K, Panda S N and Mull R 2008 Simulation modeling for efficient groundwater management in Balasore coastal basin, India; Water Resour. Manag. 22 $23-50$.

Rejani R, Jha M K and Panda S N 2009 Simulationoptimization modeling for sustainable groundwater management in a coastal basin of Orissa, India; Water Resour. Manag. 23 235-263.
Renau-Pruñonosa A, Morell I and Pulido-Velazquez D 2016 A methodology to analyse and assess pumping management strategies in coastal aquifers to avoid degradation due to seawater intrusion problems; Water Resour. Manag. 30 4823-4837.

Sefelnasr A, Gossel W and Wycisk P 2015 Groundwater management options in an arid environment: The Nubian sandstone aquifer system, Eastern Sahara; J. Arid Environ. 122 46-58.

Singh A 2010 Decision support for on-farm water management and long-term agricultural sustainability in a semi-arid region of India; J. Hydrol. 391 63-76.

Singh A 2014 Groundwater resources management through the applications of simulation modeling: A review; Sci. Total Environ. 499 414-423.

Sreekanth J and Datta B 2010 Multi-objective management of saltwater intrusion in coastal aquifers using genetic programming and modular neural network based surrogate models; J. Hydrol. 393(3-4) 245-256.

Su Z H 2005 The layout of the monitoring system of groundwater in Zhanjiang to prevent seawater invasion; Geotech. Investig. Surv. 2 17-21 (in Chinese).

Teng Y, Su J, Wang J, Dai N, Li J, Song L and Zuo R 2014 Soil microbial community response to seawater intrusion into coastal aquifer of Donghai Island, South China; Environ. Earth Sci. 72 3329-3338.

Wang X J, Li H L, Wan L, Liu F and Jiao X 2012 Loading effect of water table variation and density effect on tidal head fluctuation in a coastal aquifer system; Water Resour. Res. 48 W09501.

Wassef R and Schüttrumpf H 2016 Impact of sea-level rise on groundwater salinity at the development area western delta, Egypt; Groundw. Sustain. Dev. 2-3 85-103.

Webb M D and Howard K W F 2011 Modeling the transient response of saline intrusion to rising sea-levels; Groundwater 49(4) 560-569.

Werner A D and Simmons C T 2009 Impact of sea-level rise on sea water intrusion in coastal aquifers; Groundwater 47(2) 197-204.

Wu B, Zheng Y, Wu X, Tian Y, Han F, Liu J and Zheng C 2015 Optimizing water resources management in large river basins with integrated surface water-groundwater modeling: A surrogate-based approach; Water Resour. Res. 51 2153-2173.

Yi L, Ma B, Liu L, Tang G and Wang T 2016 Simulation of groundwater-seawater interaction in the coastal surficial aquifer in Bohai Bay, Tianjin, China; Estuar. Coast. Shelf Sci. 177 20-30.

Yidana S M, Alo C, Addai M O, Fynn O F and Essel S K 2015 Numerical analysis of groundwater flow and potential in parts of a crystalline aquifer system in Northern Ghana; Int. J. Environ. Sci. Technol. 12 3805-3818.

Yu X, Yang J, Graf T, Koneshloo M, O'Neal M A and Michael H A 2016 Impact of topography on groundwater salinization due to ocean surge inundation; Water Resour. Res. 52 5794-5812.

Zeng X, Wu J, Wang D and Zhu X 2016 Assessing the pollution risk of a groundwater source field, at western Laizhou Bay under seawater intrusion; Environ. Res. 148 586-594.

Zhang W J, Tan H B, Chen X, Cao J F, Zhang G T and Zhou H F 2012 Geochemical evolution and formation 
mechanism of groundwater in Naozhou Island, Guangdong province; J. China Hydrol. 32 51-59 (in Chinese).

Zhou P, Li G and Lu Y 2016 Numerical modeling of tidal effects on groundwater dynamics in a multi-layered estuary aquifer system using equivalent tidal loading boundary condition: Case study in Zhanjiang, China; Environ. Earth Sci. $\mathbf{7 5}$ 117 .

Corresponding editor: PRAshant K SRIVAstava
Zhou X, Chen M and Liang C 2003 Optimal schemes of groundwater exploitation for prevention of seawater intrusion in the Leizhou Peninsula in southern China; Environ. Geol. 43 978-985.

Zhou X, Yan X, Li J, Yao J and Dai W 2007 Evolution of the groundwater environment under a long-term exploitation in the coastal area near Zhanjiang, China; Environ. Geol. $51847-856$ 